\title{
Review-Electro-Kinetic Decontamination of Radioactive Concrete Waste from Nuclear Power Plants
}

\author{
Chanyoung Kim, ${ }^{1}$ Sungyeol Choi, $\mathbb{1}^{2, \mathrm{z}}$ and Myoungsu Shin $\oplus^{1, \mathrm{z}}$ \\ ${ }^{1}$ School of Urban and Environmental Engineering, Ulsan National Institute of Science and Technology, Ulju-gun, \\ Ulsan 44919, Korea \\ ${ }^{2}$ Department of Nuclear and Quantum Engineering, Korea Advanced Institute of Science and Technology, Yuseong-gu, \\ Daejeon 34141, Korea
}

\begin{abstract}
Electro-kinetic decontamination has been studied for radioactive concrete of nuclear power plants because of its effective removal of contaminants from deep inside concrete. Although many experiments have been conducted, a systematic comparison has been scarcely conducted. By a thorough review, this study reveals how different conditions of electro-kinetic decontamination changes the decontamination ratio and rate of $\mathrm{Cs}$ and $\mathrm{Co}$. The tested conditions include cell configurations (i.e., geometry of concrete waste, electrode materials, and volume of solutions) and operating conditions (i.e., types and concentrations of solutions, electric field, and test duration). The careful analysis suggests the important roles of $\mathrm{pH}$ in electrolytic solution, electric field, and pre-treatment. We also discuss the chemical conditions under which the decontamination of Cs and Co was optimized in the presence of an applied voltage. In addition, we critically review the conditions of simulated concrete samples in the previous experiments in comparison with actual nuclear plant data.

(C) The Author(s) 2018. Published by ECS. This is an open access article distributed under the terms of the Creative Commons Attribution Non-Commercial No Derivatives 4.0 License (CC BY-NC-ND, http://creativecommons.org/licenses/by-nc-nd/4.0/), which permits non-commercial reuse, distribution, and reproduction in any medium, provided the original work is not changed in any way and is properly cited. For permission for commercial reuse, please email: oa@electrochem.org. [DOI: 10.1149/2.0281809jes]
\end{abstract}

(cc) BY-NC-ND

Manuscript submitted April 9, 2018; revised manuscript received May 16, 2018. Published June 5, 2018.

Concrete is widely used in nuclear and radiological facilities because of its neutron shielding ability as well as its reliable structural performance and reasonable cost. ${ }^{1}$ A concrete shielding system against neutrons involves the transformation of stable isotopes into radioactive ones throughout the volume of the concrete (i.e., activation). ${ }^{2}$ In addition, the surface of the concrete can be contaminated by the infiltration of radioactive dust or radioactive water (i.e., contamination). Concrete waste accounts for slightly over $70 \%$ by volume, and some of this waste is radioactive at medium-to-low levels. ${ }^{3,4}$ Because of its volume, the disposal of radioactive concrete waste without appropriate decontamination has a large environmental footprint. ${ }^{5}$

Reducing the hazardous risks to which the public and the environment would be exposed requires the decontamination of radioactive concrete, the confinement of radioactive isotopes to small volumes, and the use of suitable waste forms for the isolated isotopes. ${ }^{1}$ The decontaminated concrete may be recycled as limited-quality construction materials if the concentration of radionuclides therein meets safety requirements. ${ }^{6}$ Consequently, this approach allows the volume of residual waste requiring disposal to be significantly reduced. ${ }^{3,7}$ Therefore, a decontamination method should maximize the throughput at an acceptable cost while minimizing the generation of secondary waste.

The amount of radioactive concrete waste generated around the world is expected to increase because a number of nuclear power plants (NPPs) among the over 440 NPPs in operation are scheduled for closure and decommissioning within a few decades. ${ }^{8-10}$ Until May 2015, only 11 NRC-licensed NPPs have been decommissioned completely worldwide. ${ }^{10}$ In addition, the use of nuclear power is increasing in many countries to reduce greenhouse gas emissions. ${ }^{11}$ This trend will likely leave the burden of responsibility for the sustainable management of radioactive waste on the future society. ${ }^{12}$

Decontamination methods for radioactive concrete can be categorized into mechanical and chemical techniques. ${ }^{13}$ Mechanical techniques separate radioactive isotopes from concrete by using brushing, vacuum cleaning, grinding, high-pressure water jetting, and abrasive blasting. 4,714-24 Many of the mechanical techniques are destructive or only restricted to the surfaces of radioactive concrete. ${ }^{25}$ Chemical techniques use chemical reactions with water, chemical gel, oxidants/reductants, chelating agents, or acids/bases. ${ }^{19,26-31}$
The electro-kinetic method, one of the chemical techniques, has been developed for the decontamination of radioactive concrete. ${ }^{32-42}$ It may effectively decontaminate large-scale concrete fragments and can extract radionuclides existing deep inside the concrete in a nondestructive style. ${ }^{33-42}$ This method applies electric fields through the concrete waste to activate the movement of target radioactive ions and extract them from inside the concrete. Previous electro-kinetic experiments tested various cell configurations (i.e., the geometry of concrete waste, electrode materials, and volume of solutions) and operating conditions (i.e., types and concentration of solutions, applied voltage, and test duration). ${ }^{34-41,43-46}$ However, none of the reported studies have tried to compare the results of the previous tests under different conditions to provide a comprehensive review.

Given the concern, this study analyzes and compares the results of almost all the existing electro-kinetic experimental studies regarding the decontamination of radioactive concrete waste from NPPs. By way of comparative analyses, this study examines the "effects of cell configurations and operating conditions" on the decontamination efficiency, and then suggests potential improvements for the electrokinetic methods (Evaluation of the Efficiency of Previous Decontamination Tests and Conclusion sections). In addition, the characteristics of radioactive concrete waste from NPPs are explored (Radioactive Concrete from Decommissioning of Nuclear Power Plants section), the principles of electro-kinetics in porous media are reviewed (Principles and Cell Setups of Electro-Kinetic Decontamination section), and the contamination methods used for the simulation of concrete samples in the previous studies are discussed (Specimen Contamination Methods section).

\section{Radioactive Concrete from Decommissioning of Nuclear Power Plants}

Types of radioactive waste from decommissioned NPPs.-Figs. 1 and 2 show the weight and volume of various forms of radioactive waste generated from the decommissioning of a 250-MW gas-cooled reactor (GCR), 920-MW pressurized light-water reactor (PWR), and 900 1,300-MW PWRs, respectively.,47 The vast majority of the radioactive waste consists of metal and concrete in the case of both GCRs and PWRs. Radioactive concrete waste is classified into activated and contaminated waste. Activation refers to the production of radioactive isotopes by neutron irradiation throughout the volume of concrete, and contamination means the adsorption of radioactive 


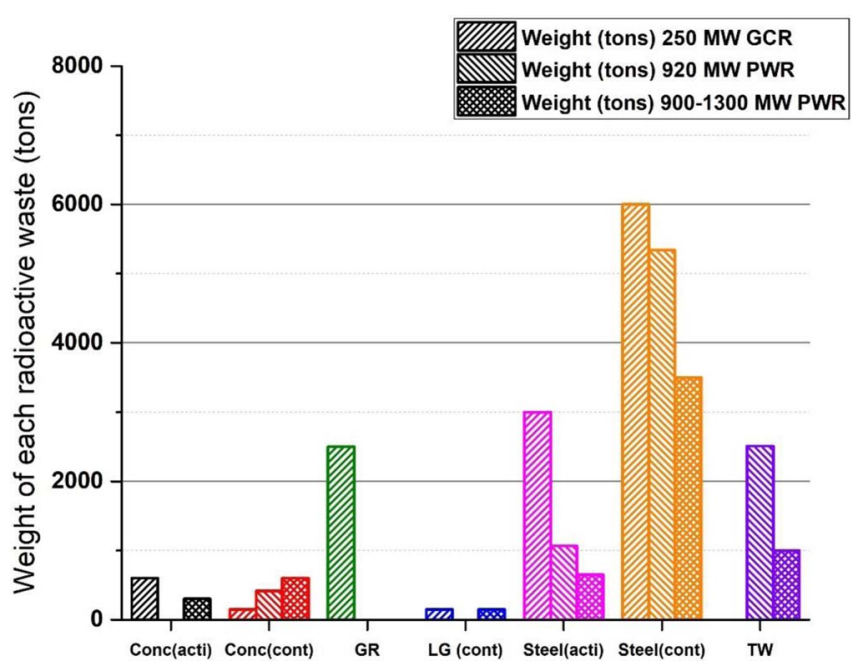

Figure 1. Weight of each form of radioactive waste from nuclear power plants. ${ }^{3,47}$ Conc $=$ Concrete, Acti $=$ Activated, Cont $=$ Contaminated, GR $=$ graphite, $\mathrm{LG}=$ Laggings, $\mathrm{TW}=$ Technological Waste .

isotopes from the surface of concrete. ${ }^{48}$ The volume of radioactive concrete comprises approximately $5.9 \%$ for GCRs and approximately $14.6 \%$ for PWRs. ${ }^{49,50}$

Major radionuclides in radioactive concrete waste.-Harms et al. and the IAEA suggested that radioactive concrete from NPPs contains the following radionuclides: ${ }^{3} \mathrm{H}$ (both fixed and mobile), ${ }^{14} \mathrm{C},{ }^{36} \mathrm{Cl}$, ${ }^{41} \mathrm{Ca},{ }^{55} \mathrm{Fe},{ }^{60} \mathrm{Co},{ }^{63} \mathrm{Ni},{ }^{133} \mathrm{Ba},{ }^{152} \mathrm{Eu}$, and ${ }^{154} \mathrm{Eu} .{ }^{51,52}$ In addition, ${ }^{60} \mathrm{Co}$ may also originate from trace constituents of both carbon and stainless steels used for reinforcement in concrete structures. The U.S. National Regulatory Commission (NRC) collected and analyzed concrete samples from bio-shield concrete walls during actual decommissioning projects. ${ }^{53,54}$ The target radionuclides selected for this analysis were ${ }_{152,}^{154,}{ }^{155} \mathrm{Eu},{ }^{60} \mathrm{Co},{ }^{54} \mathrm{Mn},{ }^{63} \mathrm{Ni},{ }^{59} \mathrm{Fe},{ }^{160} \mathrm{~Tb},{ }^{182} \mathrm{Ta},{ }^{181} \mathrm{Hf},{ }^{51} \mathrm{Cr},{ }^{124} \mathrm{Sb}$, ${ }^{134} \mathrm{Cs},{ }^{85} \mathrm{Sr},{ }^{46} \mathrm{Sc}$, and ${ }^{65} \mathrm{Zn}$.

Fig. 3 summarizes the specific activity data of radionuclides found in the concrete wall between the reactor core and the reactor vault in a 19.5-MW CANDU (Canada deuterium uranium reactor) system operated for 25 years, and the specific activity data of radionuclides detected in a concrete bio-shield of a 1175-MW PWR (Trojan reactor,

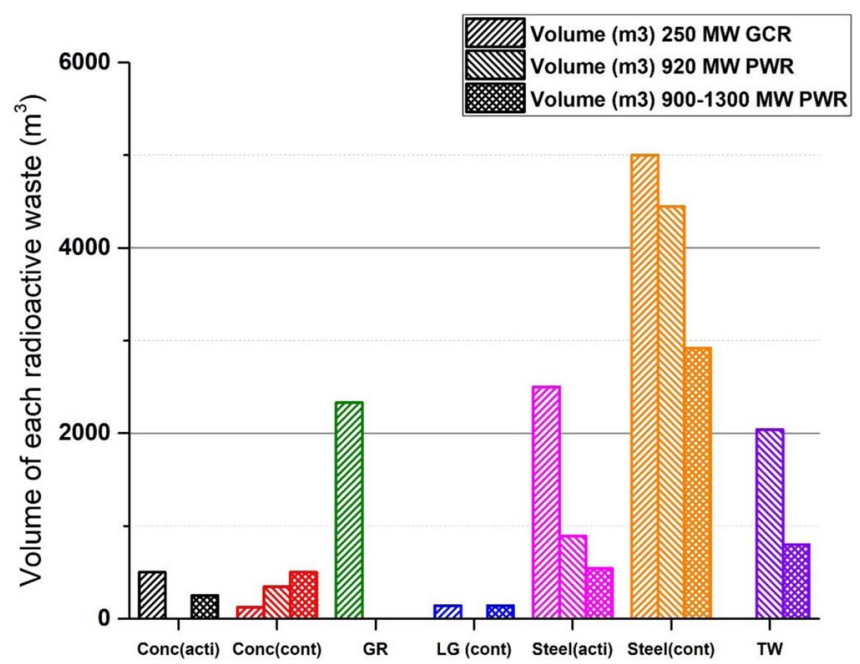

Figure 2. Volume of waste of each form of radioactive waste from nuclear power plants. $^{3,47}$ Conc $=$ Concrete , Acti $=$ Activated, Cont $=$ Contaminated, $\mathrm{GR}=$ graphite, $\mathrm{LG}=$ Laggings, $\mathrm{TW}=$ Technological Waste.

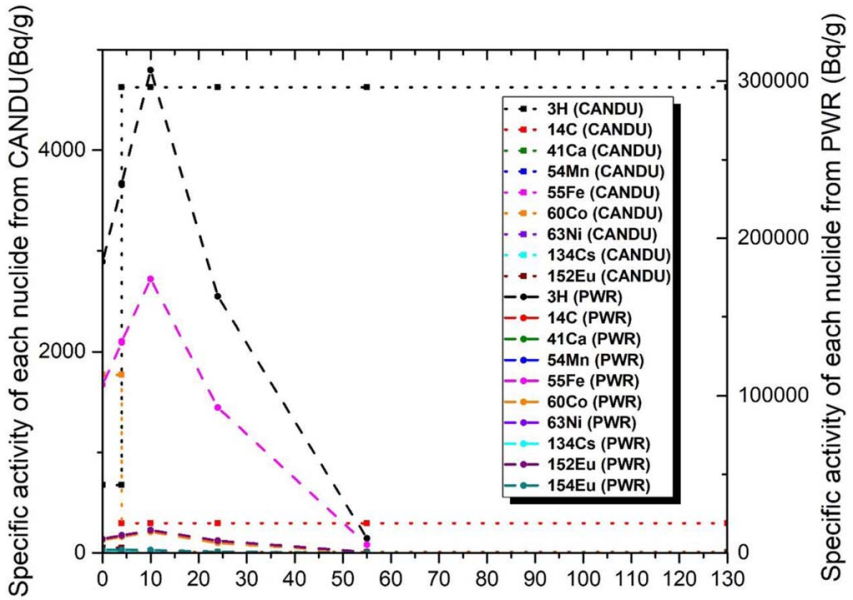

Depth from the wall surface at the reactor core side $(\mathrm{cm})$

Figure 3. Specific activity of each nuclide from an NPP as a function of the depth from the wall surface. ${ }^{53,55}$

Oregon, U.S.) system operated for 30 years. ${ }^{53,55}$ The CANDU data revealed that most metal nuclides (e.g., ${ }^{54} \mathrm{Mn},{ }^{60} \mathrm{Co},{ }^{134} \mathrm{Cs},{ }^{144} \mathrm{Ce}$, $\left.{ }^{152} \mathrm{Eu}\right)$ were detected within a depth of $4 \mathrm{~cm}$ from the surface of the wall on the side of the reactor core (Fig. 3) because metal nuclides have low mobility. ${ }^{56}$ In contrast, greater specific activities of ${ }^{3} \mathrm{H}$ and ${ }^{14} \mathrm{C}$ with relatively high mobility were observed at a depth of $4-130 \mathrm{~cm}$ from the wall surface on the side of the reactor core (Fig. 3) ${ }^{57-59}{ }^{14} \mathrm{C}$ mainly originates from the activation of neutrons ${ }^{14} \mathrm{~N}(\mathrm{n}, \mathrm{p}){ }^{14} \mathrm{C}$ existing in air or cement hydrate..$^{51,60,61}$

Among all of these nuclides, ${ }^{60} \mathrm{Co}\left(\mathrm{T}_{1 / 2}=5.27\right.$ years $),{ }^{14} \mathrm{C}\left(\mathrm{T}_{1 / 2}\right.$ $=5730$ years $)$ and ${ }^{3} \mathrm{H}\left(\mathrm{T}_{1 / 2}=12.32\right.$ years $)$ were the main sources of specific activity. ${ }^{55}$ On the other hand, ${ }^{152} \mathrm{Eu}\left(\mathrm{T}_{1 / 2}=13.54\right.$ years) is considered extremely hazardous to the environment because of their ability to emit highly penetrating gamma rays from their radioactive decay chains. In general, ${ }^{137} \mathrm{Cs}\left(\mathrm{T}_{1 / 2}=30.17\right.$ years $)$ also considered as hazardous isotopes. However, ${ }^{134} \mathrm{Cs}\left(\mathrm{T}_{1 / 2}=2.06\right.$ years) is more major in radioactive concrete than ${ }^{137} \mathrm{Cs}$, even decay modes of ${ }^{134} \mathrm{Cs}$ $\left(\beta^{-}\right.$and $\varepsilon$ ) have lower energy than decay modes of ${ }^{137} \mathrm{Cs}\left(\beta^{-}\right.$and $\left.\gamma\right)$. IAEA also revealed that, main $\gamma$ emitters in concrete were ${ }^{133} \mathrm{Ba}$, ${ }^{152} \mathrm{Eu},{ }^{154} \mathrm{Eu}$ and ${ }^{60} \mathrm{Co}$, not the ${ }^{137} \mathrm{Cs} .{ }^{51}$ Therefore, ${ }^{60} \mathrm{Co}$ and ${ }^{152} \mathrm{Eu}$ are the main heavy radionuclides that should be targeted for the decontamination of radioactive concrete waste from NPPs, when considering both radioactivity and latent hazard. ${ }^{62,63}$ In addition, ${ }^{134} \mathrm{Cs}$ could be considered as intermediate-major heavy radionuclides for the decontamination of radioactive concrete considering their specific activity in concrete.

However, in the case of PWR data, the specific activity values of nuclides differ substantially from those of CANDU data. This is deemed partly because of the differences in the type, fuel, scale, and operating time of the reactors. In case of europium, it is hard to find the data about leaching test or decontamination test, in spite of their importance in decontamination of concrete. Therefore, discussion only about the decontamination of cobalt and cesium was conducted in this paper.

Bonding forms of nuclides in radioactive concrete waste.-The bonding forms of radionuclides in radioactive concrete are important to determine the conditions under which trace elements such as cobalt, europium and cesium can be released. The chemical form of the contaminant molecular species bonded with concrete and their speciation depending on $\mathrm{pH}$ in the leaching solution are expected to influence on the efficiency of the decontamination of radioactive concrete. The possible bonding forms of cobalt in concrete are described in Fig. 4 according to Achternbosh et al. ${ }^{6}$ They suggested that cobalt may exist in the form of ions, chemical compounds (e.g., carbonate, hydrate, and oxide), physically absorbed elements (S), or substitute and incorpo- 


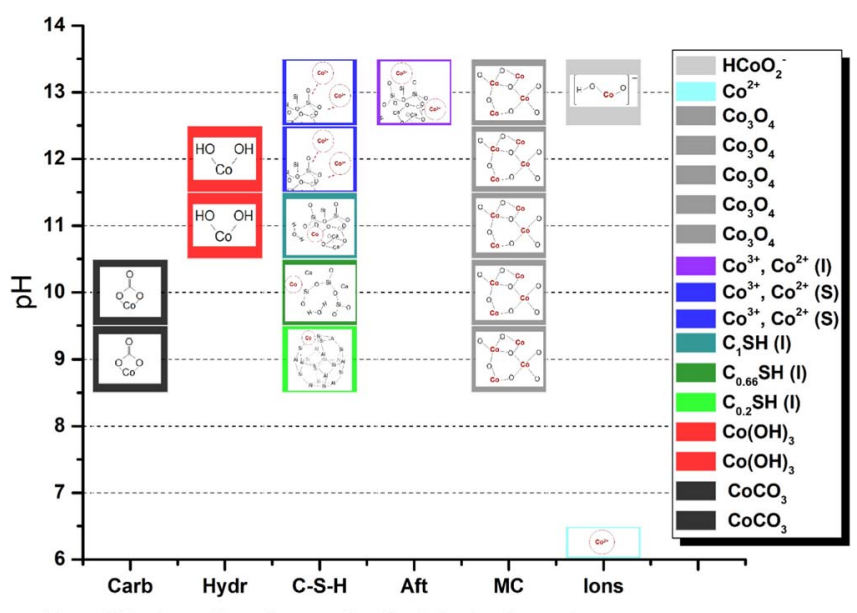

Possible bonding form of cobalt in hydrated cement systems

Figure 4. Possible bonding forms of cobalt in hydrated cement systems. ${ }^{6 *}(\mathrm{~S})$ : Sorption to existing elements, (I): Incorporation with microstructure ${ }^{*} \mathrm{Carb}=$ carbonate, $\mathrm{Hydr}=$ hydroxide, $\mathrm{MC}=$ Minor compound.

rated elements (I) of calcium silicate hydrates (C-S-Hs) when the $\mathrm{pH}$ of the concrete is higher than about six. At high $\mathrm{pH}$ values, cobalt may be strongly bonded with cement hydrates as absorbed or substitute elements, so that it may be difficult to extract a considerable portion of cobalt from the concrete. In contrast, cobalt almost always exists as $\mathrm{Co}^{2+}$ ions when the $\mathrm{pH}$ is below six, which is a highly soluble and easily removable form. ${ }^{6}$ Therefore, decreasing the $\mathrm{pH}$ of concrete may enhance the efficiency of the decontamination of radioactive concrete by increasing the mobility of various nuclides inside the concrete.

In respect of cesium in concrete, Nikolayev et al. suggested that clayey minerals and cement binder is the main source of cesium in concrete. ${ }^{64}$ In addition, they suggested that $30-50 \%$ of the ${ }^{137} \mathrm{Cs}$ in concrete is in a fixed form, and only $5 \%$ of the total amount of ${ }^{137} \mathrm{Cs}$ is highly fixed in concrete. Cesium is one of the elements that contaminates concrete by direct penetration, thus most of the cesium isotopes might bond to the concrete microstructure through adsorption. The bond characteristics of the nuclides are the chemical properties that are dominated by the number of electrons, but are less affected by the number of neutrons. Therefore, the bond behavior of ${ }^{134} \mathrm{Cs}$ in concrete is expected to be similar with that of ${ }^{137} \mathrm{Cs} .{ }^{65}$ Bar-Nes et al. suggested that the bond strength of cesium ions to cement hydrates is higher when the $\mathrm{Ca} / \mathrm{Si}$ ratio of $\mathrm{C}-\mathrm{S}-\mathrm{Hs}$ is smaller. ${ }^{66}$ The low $\mathrm{Ca} / \mathrm{Si}$ ratio is observed in pozzolanic reactions during the curing of concrete compared to the hydration reactions of $\mathrm{C}_{3} \mathrm{~S}$ and $\mathrm{C}_{2} \mathrm{~S}$.

\section{Principles and Cell Setups of Electro-Kinetic Decontamination}

Principles of electro-kinetics.-Electro-kinetic decontamination involves the motion of fluid tangential to its adjacent charged surface. ${ }^{67,68}$ Electro-kinetic phenomena could be expressed by using governing equations. According to Erickson et al., the Navier-Stokes (momentum) equation (Eq. 1), Poisson equation (Eq. 2) and NernstPlanck conservation equation (Eq. 3) are the general formulations for the potential and concentration of ionic species in an electrical double layer (EDL). ${ }^{69}$ Two equations (Eqs. 2 and 3) are coupled by the definition of the net charge density given by Eq. 4 .

$$
\rho\left(\frac{\partial v}{\partial t}+v \cdot \nabla \mathrm{v}\right)=-\nabla p+\eta \nabla^{2} v-\rho_{e} \nabla \psi
$$

Here, $v$ is the velocity, $t$ is the time, $p$ is the pressure, $\eta$ is the viscosity, $\rho$ is the density and $\psi$ is the electrical potential.

$$
\nabla \cdot\left(\varepsilon_{w} \varepsilon_{0} \nabla \psi\right)+\rho_{e}=0
$$

Here, $\varepsilon_{0}$ is the dielectric permittivity of vacuum $\left(\varepsilon_{0}=8.854 \times\right.$ $\left.10^{-12} \mathrm{C} / \mathrm{Vm}\right), \varepsilon_{w}$ is the local relative dielectric permittivity of the liquid, and $\rho_{e}$ is the net charge density.

$$
\nabla \cdot\left(-D_{i} \nabla c_{i}-\frac{D_{i} z_{i} e}{k_{b} T} c_{i} \nabla \psi+c_{i} v\right)=0
$$

Here, $D_{i}$ is the diffusion coefficient of the $i^{\text {th }}$ species, $z_{i}$ is the valence of the $i^{\text {th }}$ species, $c_{i}$ is the concentration of the $i^{\text {th }}$ species, $e\left(e=1.602 \times 10^{-19} \mathrm{C}\right)$ is the elemental charge, $k_{b}\left(k_{b}=1.380 \times 10^{-23} \mathrm{~J} / \mathrm{K}\right)$ is Boltzmann's constant, and $T$ is the temperature in the Kelvin scale.

$$
\rho_{e}=\sum_{i} z_{i} e c_{i}
$$

By assuming that the direction normal to the surface of the EDL is dominant, and there is no flux condition into the surface yielding; thus, Eq. 2 and 4 could be combined to form the Poisson-Boltzmann distribution. (Eq. 5) This equation could be linearized to the DebyeHückel approximation (Eq. 6)

$$
\begin{gathered}
\varepsilon_{w} \varepsilon_{0} \frac{d^{2} \psi}{d y^{2}}-\left(2|z| e c_{0}\right) \sinh \left(\frac{|z| e \psi}{k_{b} T}\right)=0 \\
\frac{d^{2} \psi}{d y^{2}}-\kappa^{2} \psi=0
\end{gathered}
$$

Here, $\kappa$ is the Debye-Hückel parameter $\left(\kappa=\left(2 z^{2} e^{2} c_{0} / \varepsilon_{w} \varepsilon_{0} k_{b} T\right)^{1 / 2}\right)$, and $y$ is the direction normal to the surface of the EDL. This approximation makes it possible to replace the expression of net charge in Eq. 7.

$$
\psi(y)=\zeta e^{-\kappa y}
$$

Finally, by assuming that $\nabla p$ is zero everywhere, and $-\nabla \psi$ is the applied electric field strength $E_{z}$, Eqs. 1 and 2 could be expressed as Eq. 8.

$$
\eta \frac{d^{2} v_{x}}{d y^{2}}-\varepsilon_{w} \varepsilon_{0} \frac{d^{2} \psi}{d y^{2}} E_{z}=0
$$

The Helmholtz-Smoluchowski equation is obtained by integrating Eq. 7 with respect to $y$ and by applying the boundary condition noted below:

$$
\begin{gathered}
\mathrm{y} \rightarrow \infty, \quad \frac{d v_{x}}{d y}=0, \frac{d \psi}{d y}=0, \quad \mathrm{y}=0, \quad \psi=\zeta . \\
v_{e o}=\frac{-\varepsilon_{w} \varepsilon_{0} \zeta}{\eta} E_{z}
\end{gathered}
$$

Here, $v_{e o}$ is the speed of electro-osmosis, and $\zeta$ is the zeta-potential.

Electrophoresis, which is another important mechanism for the transportation of colloidal particles, refers to the movements of colloidal particles with respect to the liquid affected by the electric field. In other words, electrophoresis is the counter-phenomenon of electroosmosis. . $^{34,45,70,71}$ The transport velocity of ions could be obtained from the Helmholtz-Smoluchowski (HS) equation for electrophoresis. ${ }^{70}$

$$
v_{r}=\frac{\varepsilon_{w} \varepsilon_{0} \zeta}{\eta} E_{z}
$$

Here, $v_{r}$ is the speed of electrophoresis. The dissolution and immobilization mechanism of a target nuclide is affected by its solubility, and thus may change its concentration and decontamination. If the solubility of a target nuclide is high, the dissolution of the nuclide dominates over the immobilization so that the decontamination may be improved.

Experimental cell setup.-Fig. 5 depicts the reference design of a typical decontamination setup. ${ }^{46}$ This setup is similar to ASTM C 1202 , which is composed of two separate electrode compartments, a concrete sample container, electrodes, electric wire, and a power supply. ASTM C 1202 is an experimental method for the determination of concrete resistance to chlorides, including both "the chloride permeability test methods and the methods for testing concrete resistance to surface scaling due to cyclic freezing and thawing in the 


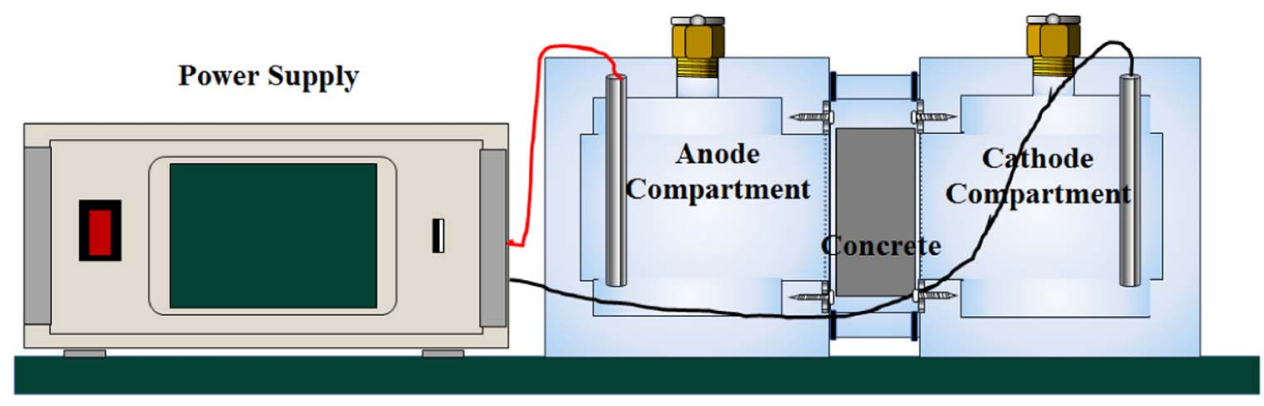

Figure 5. Fundamental design of electro-kinetic decontamination cell with reference to the illustration by Kim et al. ${ }^{46}$

presence of $\mathrm{NaCl}$ solution". ${ }^{72}$ Cylindrical concrete samples were inserted to a concrete sample container. Then, electrodes were placed in the electrode compartments, which were filled with electrolyte solution and which were connected through the concrete samples. The container was fabricated from acryl to achieve chemical resistance, thermal endurance, and visibility at reasonable cost.

As shown in Fig. 6, Kim et al. improved this reference design by adding a solution supplier and a waste reservoir for continuous operation, avoiding the need to frequently supply solution. ${ }^{46}$ The decontamination setup used by Popov et al. (Fig. 7) still adopted continuous operation, but it did not have a concrete sample container. ${ }^{41}$ The concrete block seems to be fixed by rubber and adhesive. Note that the concrete block was slightly elevated from the bottom of the cell to allow for the efficient removal of $\mathrm{H}_{2}$ bubbles. Table I lists the decontamination test setups used by different researchers. ${ }^{34-41,71,73-75}$ The comparison included the contact area between the specimen and the solution, the concentration and composition of the solution, the voltage applied across the anode and cathode, and the electrode materials.

In many experimental setups, titanium was used as a typical insoluble anode. In some cases, titanium electrodes were coated with materials such as rhodium for ultra-high resistance to acidic solutions. Graphite was typically used as the cathode. Popov et al. used graphite as the anode. Usually, electrodes were in the shape of either a metal mesh grid or cylindrical rod. ${ }^{41}$ Bostick et al. and Lomasney et al. used a concrete re-bar and pad as electrodes for testing on-site decontamination feasibility. ${ }^{34,75}$

The contact area between the electrolyte solution and concrete specimen was in the range of $0.009-2.23 \mathrm{~m}^{2}$. In most cases, the contact area was approximately $0.01-0.03 \mathrm{~m}^{2}$. Castellote et al. designed a cell with a contact area of $0.0882 \mathrm{~m}^{2}$ for their experiments on Series C specimens. ${ }^{36}$ In this case, the simulation target was the wide range of the surface of the floor, thus the volume of the specimen was also larger than in other cases.

For lab-scale experiments, the applied voltage did not exceed $60 \mathrm{~V}$, and the lowest voltage that was used was approximately $4.5 \mathrm{~V}$. Frizon et al. noted that the high temperature induced by high voltage could enhance the diffusion coefficient, which means that it seems necessary to place a limit on the temperature of the setup to allow for a clear comparison between decontamination results. ${ }^{37}$ Because the ASTM C 1202 also recommended the application of $60 \mathrm{~V}$ for chloride penetration experiments, limiting the voltage to that used in lab-scale experiments seems to reflect the specified criteria. ${ }^{72}$

The electrolytic solution was almost always acidic or basic, and deionized water was rarely used. The concentration of the solution ranged from $1 \mathrm{~mol} / \mathrm{m}^{3}$ to approximately $2000 \mathrm{~mol} / \mathrm{m}^{3}$, although the concentration was commonly $10-200 \mathrm{~mol} / \mathrm{m}^{3}$. The $\mathrm{pH}$ value was calculated from the ionization constant and the concentration of each solution.

Effects of experimental cell setup on target contaminants.-Table I also provides information about the expected effects of the $\mathrm{pH}$ of the used electrolyte solution on the contaminants in concrete samples. The $\mathrm{pH}$ values were calculated from the concentration of the solution when it is not noted in the literature. The effect of the $\mathrm{pH}$ on the leaching rate of contaminants during decontamination was estimated from the literature. The leaching rate of each nuclide with regard to $\mathrm{pH}$ in the solution used for decontamination is estimated based on the test data reported in the previous studies, ${ }^{31,74-79}$ as follows. The specimens of series A and $\mathrm{C}$ of Castellote et al., ${ }^{36}$ Frizon et al., ${ }^{37}$ and Popov et al. ${ }^{40}$ consisted of cement mortar; thus, the leaching test results of Van Gerven et al. ${ }^{76}$ and Faiz et al. ${ }^{77}$ that employed mortar specimens were used for the estimation of leaching rate. Especially, Van Gerven et al. reported test data for the effect of carbonation on the leaching rate of cobalt, so this was applied for the specimens of Castellote et al. ${ }^{36,76}$ The specimens of series B of Castellote et al., ${ }^{36}$ Popov et al., ${ }^{41}$ and Kim et al. ${ }^{39}$ involved concrete; hence, the leaching test results of Hohberg et al. ${ }^{78}$ and Nikolayev et al. ${ }^{31}$ that employed concrete specimens were used for the estimation. This leaching rate estimation is not concerned with the manufacturing process of concrete samples, which is investigated in a later section.

\section{Specimen Contamination Methods}

A few of the previous studies ${ }^{34,36,37,39,41,44,73}$ discussed the reference conditions of contaminated concretes and considered them to the simulated specimens. Although various contamination methods were proposed, they are not thoroughly validated against the actual sample conditions. ${ }^{35-37,39,40,41,43}$ Four contamination methods are analyzed against the concentration and distribution of contaminants in actual concrete samples. Each of them may be used to simulate different structures of contaminated concrete used in NPPs. Many previous studies adopted contaminant concentrations that are much higher than the real conditions under which radionuclides are used without consideration for the depth distribution of contaminants.

Contamination procedure.-Table II summarizes the methods used to produce contaminated concrete samples in the previous studies. ${ }^{34-41,71,73-75}$ Four contamination methods were used. Method 1 involved adding a solution containing the contaminants during the process of mixing the fresh concrete. ${ }^{35,36}$ In Method 2, a solution containing contaminants was poured onto hardened concrete. ${ }^{36,40}$ Method 3 entailed submerging hardened concrete in a solution containing the contaminants for a relatively long period..$^{36,37,41}$ Method 4 proceeded by shaking concrete debris within a solution containing the contaminants for a relatively short period. ${ }^{39}$ The use of these four categories of methods depended on researchers' requirements.

Each of the four methods is useful in its own right and depends on its simulation target and the dimensions of the samples. In general, the simulation target of the contamination method occurs in two varieties: the bio-shield of an NPP contaminated by a nuclear reaction, and the floor of nuclear facilities contaminated by the release of radioactive waste. $^{35-41,44}$

Method 1 is appropriate for simulating the contaminants that are strongly adsorbed to the concrete bio-shield contaminated by a nuclear reaction. This method was expected to induce strong bondage between contaminants and the concrete microstructure; thus, Method 1 is the best method to simulate the behavior of nuclides caused by activation in the bio-shield (concrete wall) of an NPP. However, as its expected 


\section{Table I. Decontamination Test Setups and Test Variables.}

\begin{tabular}{|c|c|c|c|c|c|}
\hline Authors & $\begin{array}{l}\text { Solution Contact } \\
\text { Area }\left(\mathrm{m}^{2}\right)\end{array}$ & $\begin{array}{l}{ }^{*} \text { Sol Con }\left(\mathrm{mol} / \mathrm{m}^{3}\right) \\
\text { Comp and } \mathrm{pH}\end{array}$ & ${ }^{* *} \mathrm{~V} / \mathrm{h}$ & $\begin{array}{l}\text { Used } \\
\text { Electrode }\end{array}$ & $\begin{array}{l}\text { *** Estimated leaching rate } \\
\text { of Contaminants }\end{array}$ \\
\hline Bostick et al. ${ }^{34}$ & 0.0231 & $(5.642)$ & $200 / 3$ & $\begin{array}{c}\text { Anode: Re-bar Cathode: Stainless-Steel } \\
\text { mesh }\end{array}$ & N.A. \\
\hline Lomasney et al. ${ }^{75}$ & 2.23 & $(0.114)$ & N.A./12 & Re-bar and contact pad & N.A. \\
\hline Castellote et al. ${ }^{36}$-Series B & 0.00884 & Deionized Water 7 & $12,24,60 / 720$ & Anode: Titanium Cathode: Graphite & Intermediate-high (Cs) \\
\hline Castellote et al. ${ }^{36}$-Series C & N.A. & Deionized Water 7 & $60 / 168$ & Anode: Titanium Cathode: Graphite & Low $(\mathrm{Cs})$ \\
\hline Frizon et al. ${ }^{37}$ & 0.019 & $100 \mathrm{NaOH}(11.96)$ & $12 / 480$ & $\begin{array}{l}\text { Anode: Titanium covered with } \mathrm{IrO}_{2} \\
\text { Cathode: Graphite }\end{array}$ & Intermediate-low (Cs) \\
\hline Popov et al. ${ }^{40}$ & N.A. & $\begin{array}{c}\text { Deionized Water (7) } \\
\mathrm{Na}_{2} \text { EDTA } \cdot 2 \mathrm{H}_{2} \mathrm{O}(13.4)\end{array}$ & $\begin{array}{c}45.6 / 9 \\
7.5 / 9\end{array}$ & Titanium covered with rhodium & $\begin{array}{l}\text { Almost not }(\mathrm{Cs}) \\
\text { Almost not }(\mathrm{Cs})\end{array}$ \\
\hline Popov et al. ${ }^{41}$ & $\begin{array}{l}\text { Anode: } 35 \mathrm{~cm}^{2} \\
\text { Cathode: } 446 \mathrm{~cm}^{2}\end{array}$ & $100\left(\mathrm{NH}_{4}\right)_{2} \mathrm{Na}_{2}$ EDTA (11) & $200 / 18$ & Anode: Graphite Cathode: Stainless Steel & Intermediate-low (Cs) Almost not (Co) \\
\hline Kim et al. ${ }^{39}$ & N.A. & $\begin{array}{l}100 \text { Acetic Acid (2.87) } \\
500 \text { Acetic Acid (0.7) } \\
10 \text { Acetic Acid (3.05) } \\
20 \text { Chloric Acid (3.37) }\end{array}$ & N.A./360 & Anode: DSA Cathode: - & $\begin{array}{l}\text { Intermediate-high (CS, Co) } \\
\text { Intermediate-high(CS, Co) } \\
\text { Intermediate-high (CS, Co) } \\
\text { Intermediate-high (CS, Co) }\end{array}$ \\
\hline
\end{tabular}

"N.A." indicates "not available,"

*Concentration, composition, and pH of solution (in parentheses)

** Voltage (V) and time (h) used for decontamination

***Varieties of contaminants are noted in parentheses.

Almost not: $\mathrm{x}<1 \%$

Low: $1 \%<\mathrm{x}<10 \%$

Intermediate-low: $10 \%<\mathrm{x}<30 \%$

Intermediate-high: $30 \%<\mathrm{x}<60 \%$

Intermediate-low: $10 \%<\mathrm{x}<30 \%$

Intermediate-high: $30 \%<\mathrm{x}<60 \%$

Intermediate-high (CS, Co) 
Table II. Sample contamination methods used in the previous studies.

\begin{tabular}{|c|c|c|c|c|c|c|c|c|}
\hline \multirow{2}{*}{$\begin{array}{c}\text { Author } \\
\begin{array}{c}\text { Castellote } \\
\text { et al. }\end{array}\end{array}$} & \multirow{2}{*}{$\begin{array}{c}\begin{array}{c}\text { Sample } \\
\text { Size } \\
\left(\mathrm{cm}^{3}\right)\end{array} \\
132.5\end{array}$} & \multirow{2}{*}{$\begin{array}{c}\text { Solution } \\
\text { Contact } \\
\text { Area }\left(\mathrm{cm}^{2}\right) \\
-\end{array}$} & \multirow{2}{*}{$\begin{array}{c}\text { Contamination } \\
\text { Procedure }\end{array}$} & \multicolumn{2}{|c|}{$\begin{array}{l}\text { Solution Type and Concentration } \\
\qquad\left(\mathrm{mol} / \mathrm{m}^{3}\right)\end{array}$} & \multirow{2}{*}{$\begin{array}{c}\text { Used } \\
\text { Time (h) } \\
672\end{array}$} & \multicolumn{2}{|c|}{$\begin{array}{c}\text { Concentration of Contaminants in } \\
\text { Samples }\left(\mathrm{mol} / \mathrm{m}^{3}\right)\end{array}$} \\
\hline & & & & $\begin{array}{l}\mathrm{CsCl}, \mathrm{SrCl}_{2}, \\
\mathrm{CoCl}_{2}, \mathrm{FeCl}_{3}\end{array}$ & 1 & & $\mathrm{Cs}, \mathrm{Sr}, \mathrm{Co}, \mathrm{Fe}$ & 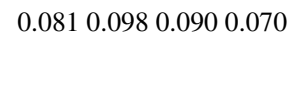 \\
\hline $\begin{array}{c}\text { Castellote } \\
\text { et al. } .^{36} \text {-Series A }\end{array}$ & 132.5 & - & $\begin{array}{l}\text { Adding a solution of } \\
\text { contaminants during mixing } \\
\text { (Method } 1)\end{array}$ & $\begin{array}{l}\mathrm{CsCl}, \mathrm{SrCl}_{2} \\
\mathrm{CoCl}_{2}, \mathrm{FeCl}_{3}\end{array}$ & 1 & 672 & $\mathrm{Cs}, \mathrm{Sr}, \mathrm{Co}, \mathrm{Fe}$ & 0.0810 .0980 .0900 .070 \\
\hline $\begin{array}{c}\text { Castellote } \\
\text { et al. }{ }^{36} \text {-Series B }\end{array}$ & 331.3 & 44.2 & $\begin{array}{l}\text { Pour solution onto cast } \\
\text { specimen (Method 2) }\end{array}$ & $\begin{array}{l}\mathrm{CsCl}, \mathrm{SrCl}_{2}, \\
\mathrm{CoCl}_{2}, \mathrm{FeCl}_{3}\end{array}$ & 25 & 72 & Cs & 0.151 \\
\hline $\begin{array}{c}\text { Castellote } \\
\text { et al. }{ }^{36} \text {-Series C }\end{array}$ & 3478 & 869.5 & $\begin{array}{l}\text { Pour solution onto cast } \\
\text { specimen (Method 2) }\end{array}$ & $\begin{array}{l}\mathrm{CsCl}, \mathrm{SrCl}_{2}, \\
\mathrm{CoCl}_{2}, \mathrm{FeCl}_{3}\end{array}$ & 40 & 408 & $\mathrm{Cs}, \mathrm{Sr}, \mathrm{Co}, \mathrm{Fe}$ & 5.18 \\
\hline Frizon et al. ${ }^{37}$ & 171.1 & 252.2 & $\begin{array}{l}\text { Submerge cast specimen in } \\
\text { solution and apply voltage } \\
\text { (Method 3) }\end{array}$ & $\mathrm{CsCl}, \mathrm{CoCl}_{2}$ & 1 & 250 & Cs & 0.39 \\
\hline Popov et al. ${ }^{40}$ & 207.3 & N.A. & $\begin{array}{l}\text { Deposit solution onto small } \\
\text { area (Method 2) }\end{array}$ & $\mathrm{CsCl}, \mathrm{CoCl}_{2}$ & 400 & 75 & Cs & 0.109 \\
\hline Popov et al. ${ }^{41}$ & 312 & 334 & $\begin{array}{l}\text { Submerge cast specimen in } \\
\text { solution (Method 3) }\end{array}$ & $\begin{array}{l}{ }^{134} \mathrm{CsCl} \\
{ }^{60} \mathrm{CoCl}_{2}\end{array}$ & $\begin{array}{l}2.21 \times 10^{-5} \\
2.21 \times 10^{-9}\end{array}$ & 72 & ${ }^{134} \mathrm{Cs}{ }^{60} \mathrm{Co}$ & $1.48 \times 10^{-8} 2.2 \times 10^{-11}$ \\
\hline Kim et al. ${ }^{39}$ & N.A. & N.A. & $\begin{array}{l}\text { Shake concrete debris with } \\
\text { solution (Method 4) }\end{array}$ & $\mathrm{CsCl}, \mathrm{CoCl}_{2}$ & 10 & 168 & Cs, Co & 6.5456 .329 \\
\hline
\end{tabular}

"N.A.” indicates "not available," “-_" indicates "not applicable” 


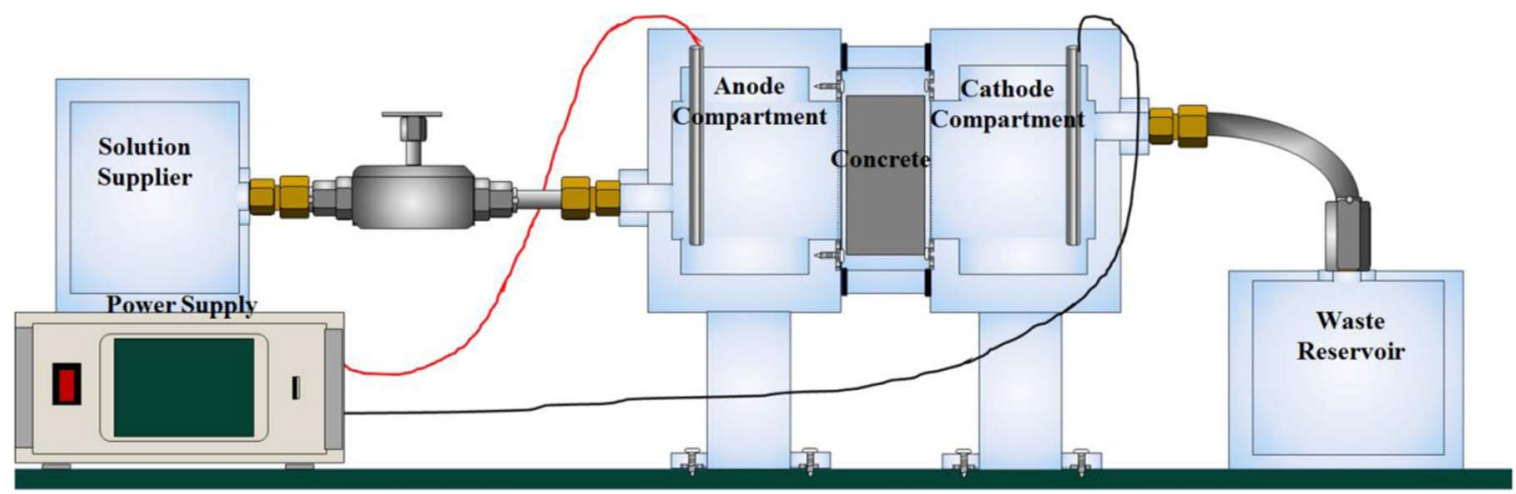

Figure 6. Modified design of electro-kinetic decontamination cell - adopted from Kim et al. ${ }^{46}$

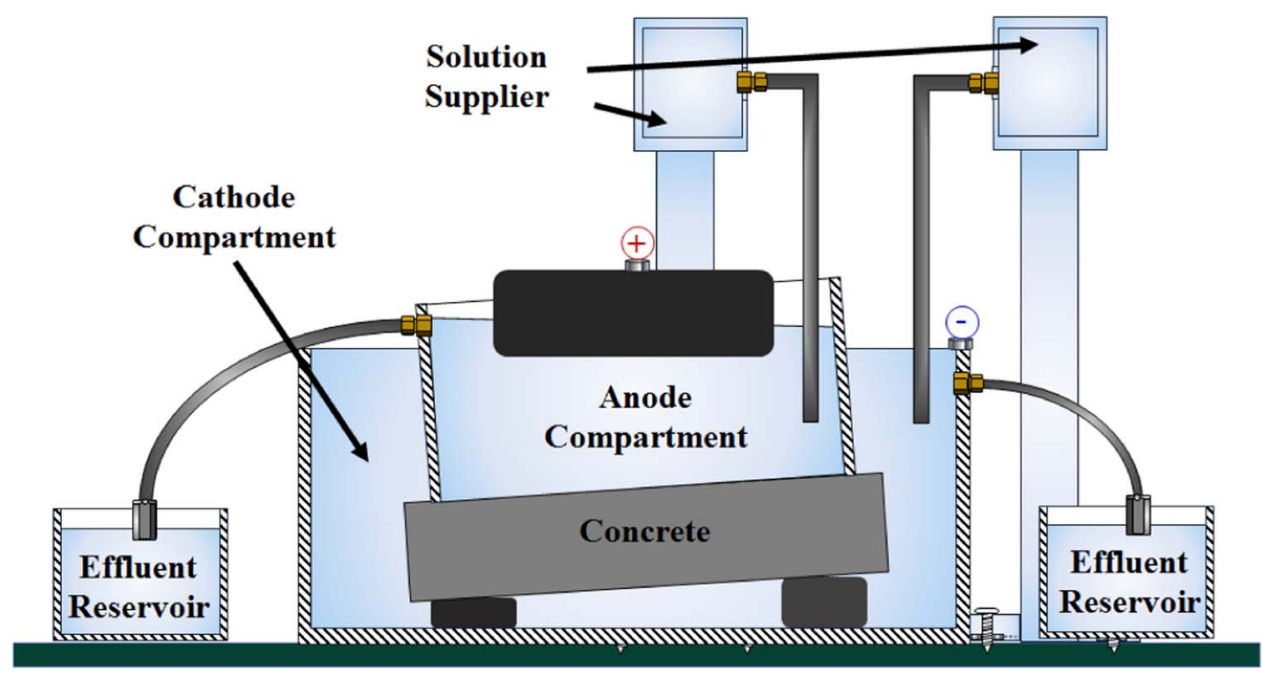

Figure 7. Design of electro-kinetic decontamination cell. Adopted from Popov et al. ${ }^{41}$

distribution differs from that in the bio-shield, it could be hard to simulate the entire bio-shield. Instead, it is appropriate to simulate a fraction thereof.

Method 2 is appropriate for simulating the facilities contaminated by the release of radioactive waste, but could also be used to simulate the bio-shield structure in a limited way. When using this method, the resulting chemical bond between contaminants and the concrete microstructure could be weaker than in the other two methods (Method 1 and 4), thus, the period during which contamination takes place should be sufficiently long. The resulting distribution of contaminants was concentrated on one surface, thus simulating both structures would be more effective. However, its characteristics (contamination scale, lack of expected vertical distribution in the bio-shield) differ from those of the bio-shield, and these points should be considered for analysis.

The results of Method 3 and Method 4 are expected to be similar with those of Method 1. However, because the starting contact between concrete and contaminants solution in Method 3 is later than Method 1 , it was expected to show relatively weak bondage between the contaminants and the concrete microstructure, compared to Method 1. In contrast the target object of Method 4 is much smaller than Method 1 and 3, so specimen produced by Method 4 can has relatively strong bondages than Method 3. Therefore, Method 3 and Method 4 are appropriate to simulate the fraction of an area contaminated by an accidental release. The results of Method 4 are expected to simulate a small fraction of the concrete bio-shield in a limited way.

Distribution of contaminants by target object of each method.The distribution of radioactive nuclides in the PWR bio-shield is depicted in Fig. 8. All maximum values of the radioactivity of each nuclide were observed at a depth of approximately $10 \mathrm{~cm}$, and then, sharply decreased until a depth of $55 \mathrm{~cm}$. The concentration of ${ }^{60} \mathrm{Co}$ is approximately 20 times higher than that of ${ }^{134} \mathrm{Cs}$. This profile seems to be the consequence of the mechanism of contamination and activation. The radioactive nuclides in concrete can originate either from

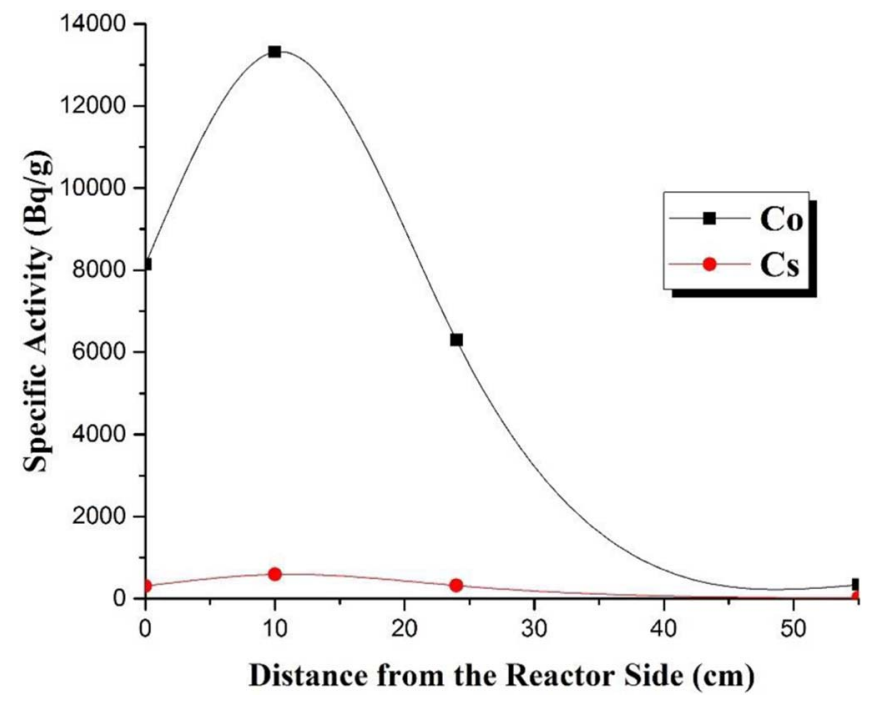

Figure 8. Profiles of Cs and Co in the PWR bio-shield - Adopted from Evans et al. ${ }^{53}$ 


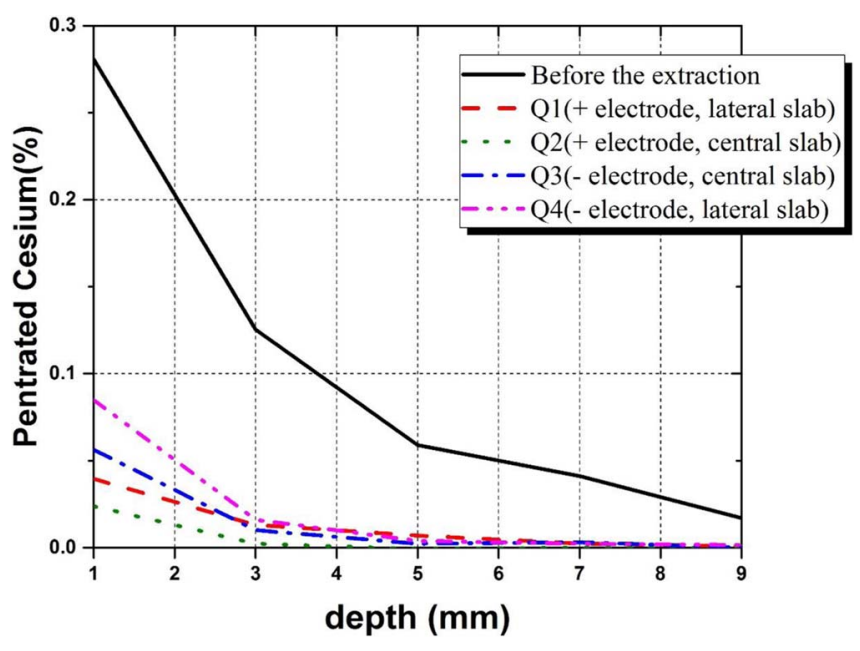

Figure 9. Profiles of $\mathrm{Cs}^{+}$in the slab - Adopted from Castellote et al. ${ }^{36}$

penetration from the exterior (contamination) or from nuclear transformation (activation). Activation through radiation occurred for tens of centimeters, whereas penetration does not proceed beyond tens of millimeters. Therefore, the radioactivity at $10 \mathrm{~cm}$ is higher than surface radioactivity.

When using Method 1, the distribution of contaminants is close to uniform throughout the entire sample. In the case of series A of Castellote et al., a solution of contaminants was added to and blended with fresh concrete in the plastic state while the concrete was being mixed. ${ }^{36}$ During the hydration phase, the quasi-uniformly distributed surrogate becomes hydrated in the concrete microstructure. Consequently, this method is appropriate to simulate the strong chemical bond of nuclides in the concrete wall. However, the resulting distribution of contaminants might be different from that in a real concrete bio-shield. Because a great portion of nuclides is typically located closer to the surfaces of concrete structures in NPPs, specimens that simulate the entire concrete wall should involve a non-uniform distribution of contaminants.

Thus, the specimen produced by Method 1 is not appropriate to simulate the entire depth of the bio-shield structure. Instead, because of strong chemical bond of contaminants, Method 1 can be used to simulate contaminants that are tightly fixed in concrete and that originated from activation. If it is only necessary to simulate a fraction of the inner area of the bio-shield, Method 1 could be the appropriate method for producing a specimen.

Method 2 involves pouring a solution of contaminants into cured concrete samples. Thus, the resulting distribution differs from the quasi-uniform distribution, as in Method 1. Fig. 9 shows the cesium distribution in a slab produced by Method 2, and it is possible to verify that the contaminant was non-uniformly distributed along the depth of the specimen. The profile corresponds well with the distribution of nuclides in the concrete bio-shield. However, three points should be considered when investigating this similarity and when applying this method to producing a simulant.

The first is the difference in scale. In a real structure, nuclides were distributed for tens of centimeters, but in the specimen, contaminants were distributed for several millimeters. The second issue is the effects of gravity. In a bio-shield, the distribution in Fig. 8 is along its horizontal axis, whereas another distribution tendency along its vertical axis should exist. However, it is difficult to achieve a distribution for the simulant produced by this method such that it corresponds to the distribution along the vertical axis in the case of a real bio-shield. The third point concerns the chemical bonding energy of contaminants with a cement matrix. Series B of Castellote et al. showed that bonds between contaminants and samples could be weaker than in samples produced by Method $1 .^{36}$ Thus, simulation of the chemical bonding of nuclides in the concrete bio-shield still needs to be investigated.

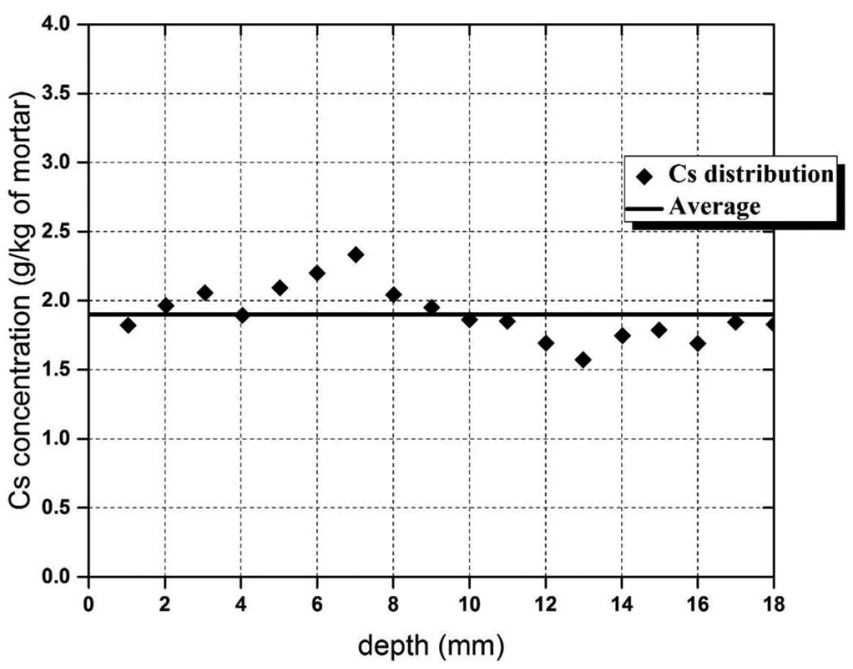

Figure 10. Cs distribution throughout the mortar sample at the end of the contamination phase -Adopted from Frizon et al. ${ }^{37}$

In conclusion, considering the process of this method, the characteristics of the chemical bonding of contaminants should be similar to those of the radionuclides on floors contaminated by the accidental release of nuclides. Resultantly, Method 2 can be used to effectively simulate the distribution of contaminants in an area contaminated by the accidental release of radioactive material. However, simulation of the strong bonding of contaminants to simulate the bio-shield seems required more investigation.

The use of Method 3 affects the distribution of contaminants in concrete samples in a complicated manner. Frizon et al. ${ }^{37}$ and Popov et al. ${ }^{41}$ used a contamination procedure that involved submerging concrete samples in a solution of contaminants. Additionally, Frizon et al. ${ }^{37}$ applied an electric field to the solution and the concrete samples, and found that contaminants were transported along the direction of the applied voltage. The samples were expected to reach equilibrium at a certain stage. Fig. 10 describes the distribution of cesium in samples produced by Method 3 and shows that this estimation is partially valid. It is possible to verify that the maximum cesium concentration at a certain depth was $60 \%$ higher than the minimum value. This difference was significantly lower than the profile reported in Figs. 8, and the abstract shape of the distribution is close to being uniform. From this point of view, it should be possible to use Method 3 in a manner similar to Method 1.

The procedure of Method 4 and the resulting distribution of contaminants were expected to be similar to that of Method 1 and Method 3. The main difference is the range of the dimensions of the samples. Kim et al. shook the concrete debris with a solution containing the contaminants, thus the particle size is mostly smaller than $5 \mathrm{~mm} .{ }^{74}$ Method 4 is expected to achieve the target concentration of contaminants in the sample faster than the other three methods, because, in Method 4, the area of the concrete samples in contact with the contaminants is wider than in the other methods. From this point of a view, the simulation target of Method 4 is most similar to that of the small debris of a crushed concrete wall contaminated by the release of radioactive material.

Target concentration for contamination according to the dimension of samples.-The advantages and disadvantages of each detailed procedure were compared by investigating the time spent for contamination and the concentration of contaminants, as shown in Figs. 11 and 12 . In many cases, ${ }^{35,36,39,41,44,73}$ various contaminants were simultaneously used for contamination. The literature review verified that the diffusion coefficients of cesium and cobalt do not affect each other. ${ }^{80}$ Therefore, in specimens in which several contaminants 


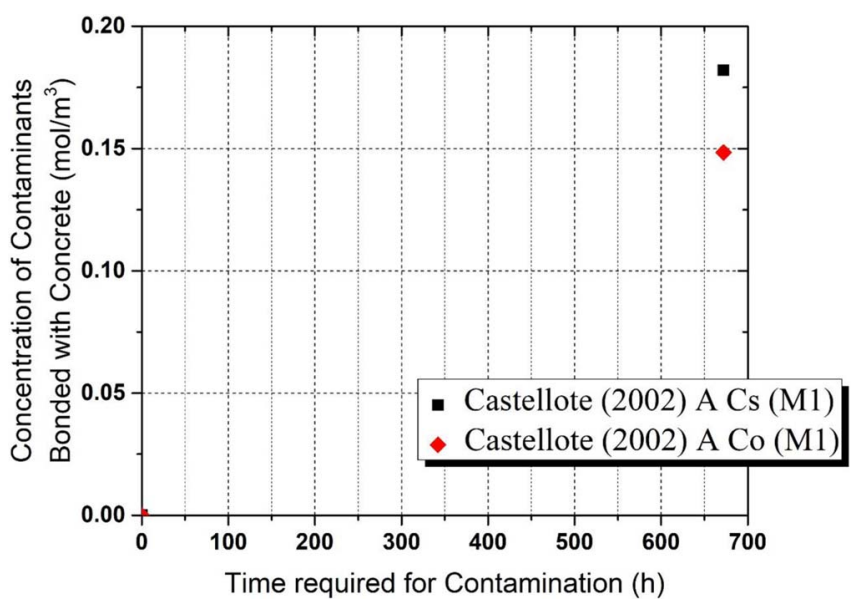

Figure 11. Concentration of contaminants bonded with concrete vs. consumed time (for Method 1).

are used simultaneously, the trend of each contaminant is described separately.

The difference between the maximum and minimum values of the concentration of contaminants was approximately eighty times. In the case of Method 1, a concentration of $0.081 \mathrm{~mol} / \mathrm{m}^{3}$ was the target value for cesium in the work of Castellote et al. ${ }^{36}$ The concentrations of the other contaminants targeted by the same research were similar. In terms of mass concentration units, the value was $29.274 \mathrm{~g} / \mathrm{m}^{3}$.

In the case of Method 2, the range of the target concentration was $0.151-5.18 \mathrm{~mol} / \mathrm{m}^{3}{ }^{36,40}$ Castellote et al. used various elements in Series $\mathrm{C}$, and the molar concentration of each individual contaminant was approximately $5.17 \mathrm{~mol} / \mathrm{m}^{3}{ }^{36}$ The concentrations of contaminants in Method 2 were estimated under the assumption that all contaminants in the solution were absorbed into the concrete specimen.

In the case of Method 3, Frizon et al. used a concentration of $0.39 \mathrm{~mol} / \mathrm{m}^{3}$. ${ }^{37}$ However, in the case of Method 4, the range of the target concentration was difficult to estimate from the previous papers because this information was not always provided. Kim et al. noted that $1 \mathrm{M}$ of cesium and cobalt were used for contamination, but did not mention the mass of the concrete, hence it was difficult to estimate the concentration of contaminants. ${ }^{39}$ In separate research, Kim et al. used approximately $238 \mathrm{mg} / \mathrm{kg}$ of cobalt and $514 \mathrm{mg} / \mathrm{kg}$ of cesium for the contamination of soil. ${ }^{46}$ Applying these values to concrete, the resulting concentration is about $6.4 \mathrm{~mol} / \mathrm{m}^{3}$ for each of the contaminants; thus, we decided to use this value for estimation.

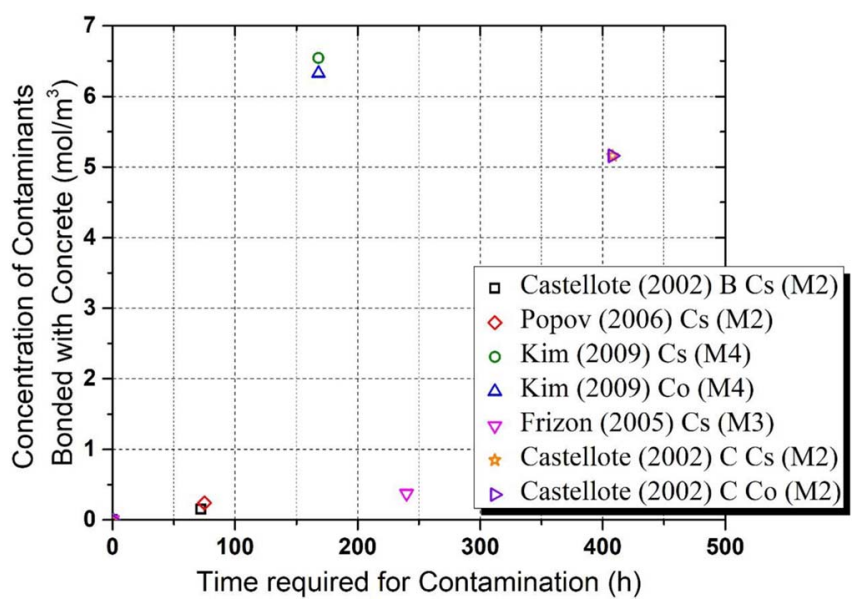

Figure 12. Concentration of Contaminants Bonded with Concrete vs Consumed Time graph (for Method 2, 3, and 4).
As a result, the target concentration of contaminants in previous studies was between $0.081-6.4 \mathrm{~mol} / \mathrm{m}^{3} .{ }^{36,37,39,40}$ However, based on the information provided earlier it is possible to verify that the concentration of radionuclides in structures of an NPP was much lower that this value. The number of radioactive nuclides can be calculated by a simple equation. ${ }^{81}$

$$
m_{i}=\frac{a_{i} * t_{i \frac{1}{2}}}{\ln (2) * N_{A}}
$$

Here, $m_{i}$ is the specific number of mol of radionuclides in concrete samples ( $\mathrm{mol} / \mathrm{g}), a_{i}$ is the specific radioactivity of radionuclides $(\mathrm{Bq} / \mathrm{g}), t_{i \frac{1}{2}}$ is the half-life of nuclides $i$ in concrete samples (s), and $N_{A}$ is the Avogadro constant $\left(6.022 \times 10^{23} \mathrm{~mol}^{-1}\right)$. The calculated specific molar number could be converted to molar concentration.

$$
n_{i}=m_{i} * 1000 * d_{i}
$$

Here, $m_{i}$ is the molar concentration of radionuclides in concrete samples $\left(\mathrm{mol} / \mathrm{m}^{3}\right), 1000$ is the conversion factor $(\mathrm{kg} / \mathrm{g})$, and $d_{i}$ is the density of concrete samples $\left(\mathrm{kg} / \mathrm{m}^{3}\right)$.

The converted molar concentration of radionuclides in data suggested by Krasznai et al. was in the range of $5.7 \times 10^{-10}-1.61 \times 10^{-6}$, which is much lower than the concentration range of the contaminant targeted in previous studies. ${ }^{55}$

The molar concentration of cobalt (including non-radioactive cobalt) in radioactive concrete was about $1.94 \times 10^{-3} \mathrm{M} .{ }^{55}$ It is approximately six times higher than the concentration of cobalt in concrete comprising gravel/sand aggregates, and two times higher than basalt/slag aggregate concrete. ${ }^{6}$ In the work of Evans et al., the concentration of cobalt is in the range of $0.04 \times 10^{-3}-1.25 \times 10^{-3} \mathrm{M}$, and the concentration of cesium is approximately $0.57 \times 10^{-5}-11.01 \times 10^{-5}$ M. ${ }^{53}$

The measurement limits of devices such as ICP, AAS, and EDX could be the reason for the experimental design targeting higher concentrations of contaminants. ${ }^{37}$ Moreover, concentrations in the $10^{-6} \mathrm{M}$ range are too low to control the quality and reliability of concrete samples. Despite higher contaminant concentrations in the previous tests compared with real NPP structures, the concentration of contaminants is sufficiently low in most tests, so as to be barely affected by the solubility of them. As a result, the migration of contaminants from concrete to solution is likely to occur smoothly. Furthermore, in real NPP structures with lower concentrations of nuclides, precipitation due to immobilization is expected not to occur.

The use of the decontamination results to correctly estimate the decontamination efficiency in a real NPP requires the difference in the concentration of contaminants between the real structure and the specimen to be considered. Considering the high target concentration used by Kim et al., the termination time was lower than that of others. ${ }^{39}$ Kim et al. used very small target debris; thus, the contact area was larger than that of the other specimens. ${ }^{39}$ Furthermore, in series $\mathrm{C}$ of Castellote et al. the specimen was slab-shaped, which means that the effective contact area was larger than that of a specimen with a cylindrical shape. ${ }^{36}$

\section{Evaluation of the Efficiency of Previous Decontamination Tests}

The results of the previous decontamination tests are summarized and compared in Table III. ${ }^{34-41,71,73-75}$ The efficiency evaluation of the previous decontamination tests with different conditions requires a rational analysis to investigate the multiple effects of several setups. Thus, we considered only those studies that reported all the information required for the analyses and for the calculation of the number of contaminants transported from the concrete. Data from the studies of Bostick et al., Lomasney et al., Popov et al., and Castellote et al. are excluded from the efficiency evaluation, because they did not report the molar concentration of the targeted contaminants in concrete samples and simply presented the radioactivity of the radioactive contaminants. ${ }^{34,35,41,73,75}$ 
Table III. Decontamination Results from Various Studies.

\begin{tabular}{|c|c|c|c|c|}
\hline Authors & $\begin{array}{c}\text { *Estimated leaching rate of } \\
\text { Contaminants }\end{array}$ & ${ }^{* *} \mathrm{~V} / \mathrm{m} / \mathrm{h}$ & $\begin{array}{c}* * * \text { Estimated Bonding forms of } \\
\text { Cobalt }\end{array}$ & $\begin{array}{c}\text { Decontamination Efficiency (\%) } \\
\text { and Target Elements }\end{array}$ \\
\hline Castellote et al. ${ }^{35}$ & N.A. & $2000 / 720$ & N.A. & $97(\mathrm{Cs})$ \\
\hline Castellote et al. ${ }^{36}$-Series A & N.A. & $2000 / 720$ & N.A. & $\begin{array}{c}96 \text { (Cs-non-carbonated) } \\
40 \text { (Cs-carbonated }) \\
4 \text { (Co-non-carbonated }) \\
38 \text { (Co-carbonated })\end{array}$ \\
\hline Castellote et al. ${ }^{36}$-Series B & Intermediate-high (Cs) & $320 / 720$ & N.A. & $98(\mathrm{Cs})$ \\
\hline \multirow{2}{*}{ Popov et al. ${ }^{40}$} & Almost not (Cs) & $306.67 / 9$ & N.A. & $36.9(\mathrm{Cs})$ \\
\hline & Almost not (Cs) & $500 / 9$ & N.A. & $61.5(\mathrm{Cs})$ \\
\hline Popov et al. ${ }^{41}$ & $\begin{array}{c}\text { Intermediate-low (Cs) Almost } \\
\operatorname{not}(\mathrm{Co})\end{array}$ & N.A./18 & $\mathrm{Co}_{3} \mathrm{O}_{4}, \mathrm{C}_{1} \mathrm{SH}(\mathrm{I}), \mathrm{Co}(\mathrm{OH})_{3}$ & $30.76(\mathrm{Cs}) 40.37(\mathrm{Co})$ \\
\hline \multirow[t]{2}{*}{ Kim et al. ${ }^{39}$} & Intermediate-high (CS, Co) & $400 / 360$ & $\mathrm{Co}^{2+}$ & $0.8(\mathrm{Co}), 55.0(\mathrm{Cs})$ \\
\hline & Intermediate-high (CS, Co) & & $\mathrm{Co}^{2+}$ & $1.0(\mathrm{Co}), 65.0(\mathrm{Cs})$ \\
\hline
\end{tabular}

\footnotetext{
"N.A." indicates "not available,"

(I): Incorporated with cement matrix

Almost not: $\mathrm{x}<1 \%$

Low: $1 \%<\mathrm{x}<10 \%$

Intermediate-low: $10 \%<\mathrm{x}<30 \%$

Intermediate-high: $30 \%<x<60 \%$
}

*Varieties of contaminants are noted in parentheses.

**Electric field $(\mathrm{V} / \mathrm{m})$ and time $(\mathrm{h})$ used for decontamination.

*** Estimation about bonding forms of cesium was excluded because of lack of information

Correlation analysis between experimental setup and decontamination result.-In the previous section, it is verified that specimens manufactured by different methods have very different characteristics. In addition, in some cases, several elements were used simultaneously for contamination; thus, a rational comparison requires these kinds of data to be classified by their target elements. Therefore, several graphs were drawn separately according to their target elements. In some cases, the data required for estimation of the time used for decontamination were not reported; hence, they were estimated using simple calculations.

For example, Fig. 13 shows the current as a function of time in each concrete sample from Castellote et al. ${ }^{36}$ The average current of samples to which $24 \mathrm{~V}$ was applied was $14 \mathrm{~mA}$ and $2.4 \mathrm{~mA}$

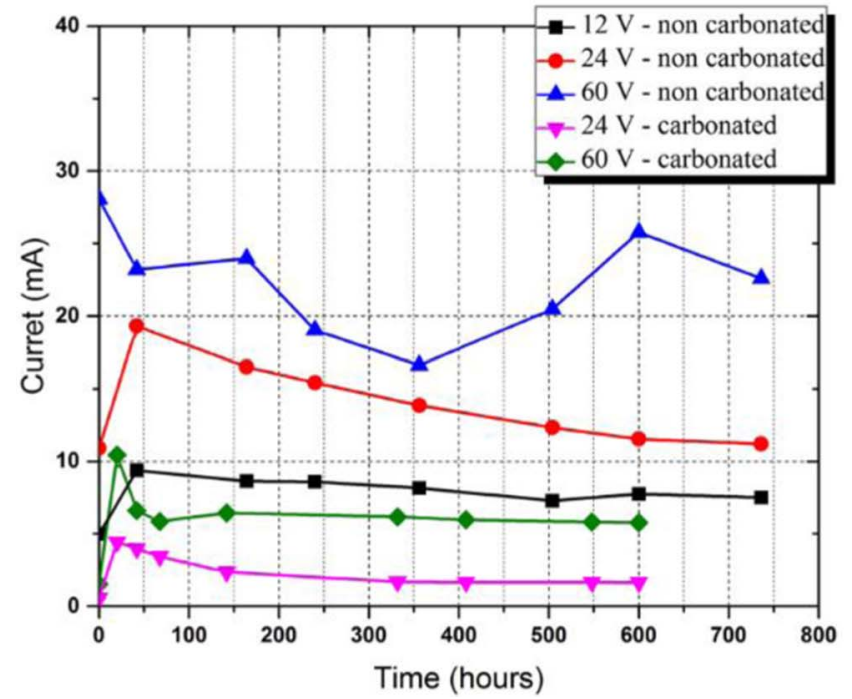

for the non-carbonated and carbonated specimens, respectively. The relationship between the time and the charge density applied during a decontamination experiment can be expressed by Eq. 13. These equations were used to convert charge density to time. For example, the diameter of the cylindrical specimen used in Castellote et al. was $75 \mathrm{~mm}$ for both Series-A and Series-B. ${ }^{36}$ The duration of the experiment in which $24 \mathrm{~V}$ was applied to the contaminated specimen was briefly estimated as 1063 hours, using Eq. 13.

$$
t=\frac{\rho_{c} \pi d^{2}}{4 I}
$$

Here, $I$ is the average electric current (A), $\rho_{c}$ is the charge density $\left(\mathrm{C} / \mathrm{m}^{2}\right)$, and $d$ is the diameter of the cylindrical specimen.

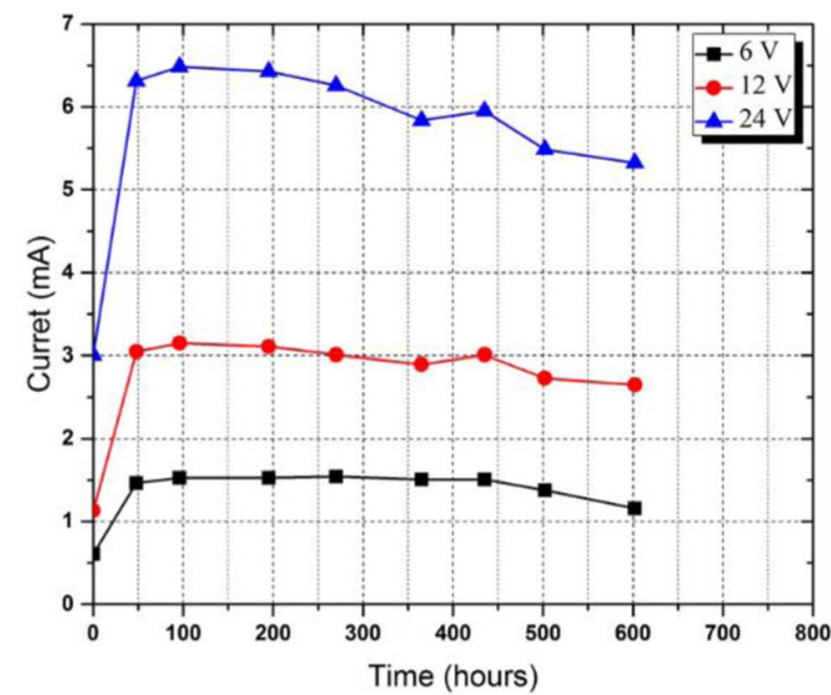

Figure 13. Current change in Series A(left), Series B(right) during decontamination-Adopted from Castellote et al. ${ }^{36}$ 


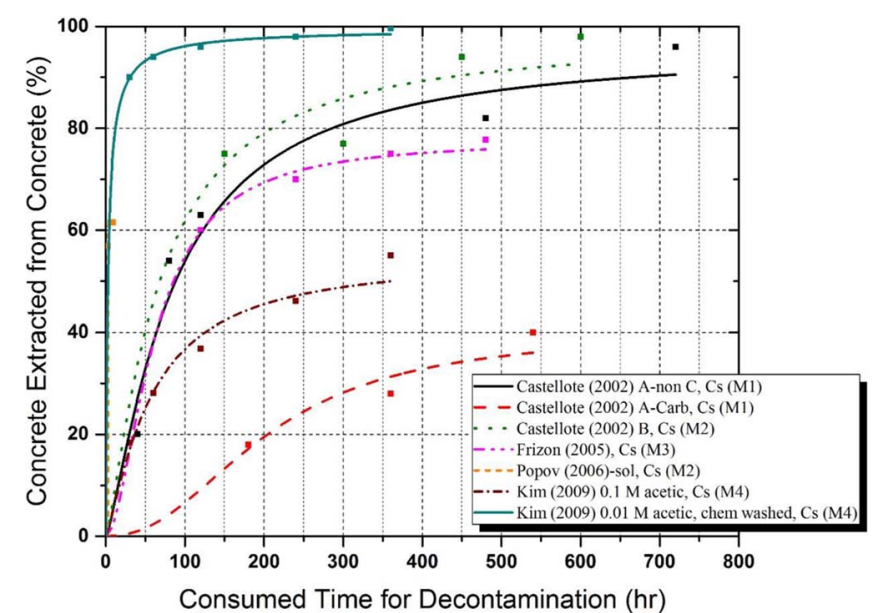

Figure 14. Contaminants extracted from concrete vs. consumed time (Cesium).

Fig. 14 shows the results of the decontamination test of cesium in a previous study in percentage. The experiment of Kim et al. used $0.01 \mathrm{M}$ acetic acid with a chemical washing process, and that of Popov et al. showed the fastest decontamination. ${ }^{39,40}$ The $\mathrm{pH}$ of the solution used in each of these experiments was 3.37 and 14. Earlier in this paper, the effects of $\mathrm{pH}$ on the cumulative leaching rate were mentioned, and in the case of cesium, it is estimated that a $\mathrm{pH}$ value lower than 6 or higher than 8 could improve the leaching of cesium. The performance of those two experiments could be improved by improving the leaching of cesium.

In terms of the final decontamination ratio, the experiments of Kim et al., using $0.01 \mathrm{M}$ acetic acid with a chemical washing process and the series $\mathrm{B}$ experiments of Castellote et al. provided the best results. ${ }^{36,39}$ Considering this result, the contamination method could also be an important factor to improve the decontamination result. The respective specimens of Popov et al. and from series B of Castellote et al. were manufactured by Method 2, and it is verified that the bonding energy of contaminants in these specimens could be lower than that of the specimens of other researchers. ${ }^{36,40}$ Initially, the decontamination speed of the other specimens is similar; however, the experiment of Castellote et al. using carbonated samples of series A exhibit a lower decontamination speed and final decontamination ratio than the others. ${ }^{36}$

Fig. 15 shows the results of the decontamination test of the previous study of cobalt in percentage units. ${ }^{36,39}$ The experiment of Kim et al.

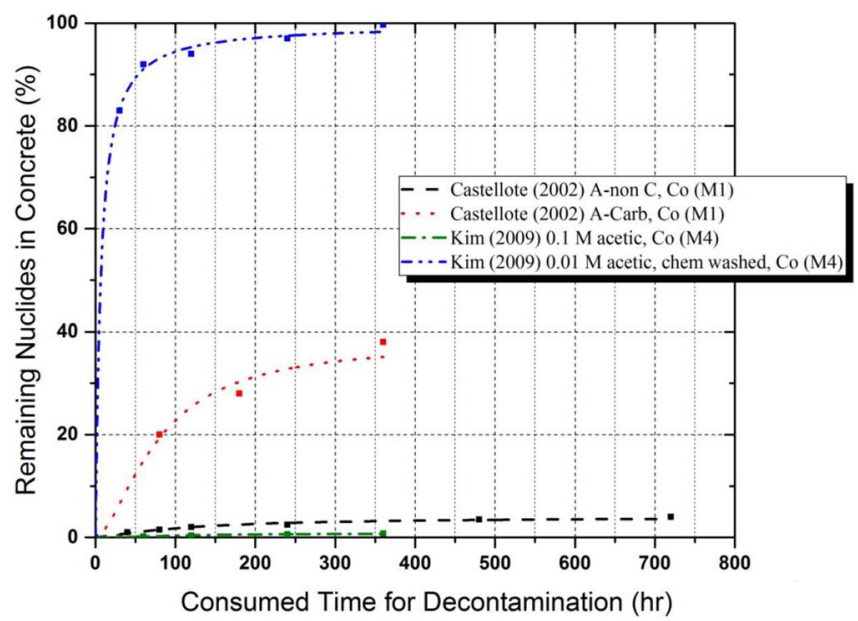

Figure 15. Contaminants extracted from concrete vs. consumed time (cobalt).

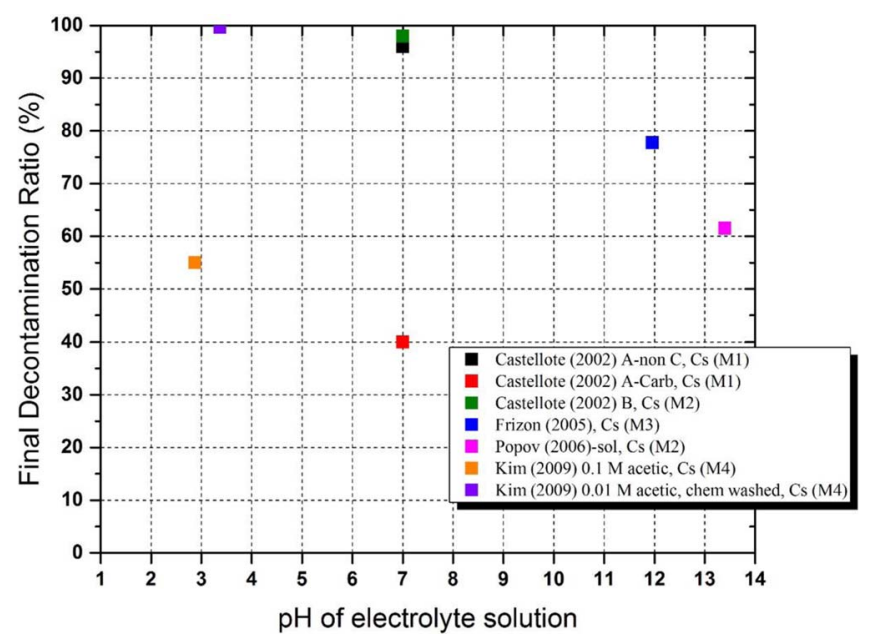

Figure 16. Final decontamination ratio vs. pH (cesium).

using $0.01 \mathrm{M}$ acetic acid with a chemical washing process shows the highest decontamination rate, ${ }^{39}$ whereas that of Castellote et al. using carbonated samples of series A (using Method 1) shows the second highest decontamination rate. ${ }^{36}$ Except for these experiments, most of the cobalt was not extracted during decontamination. In general, $\mathrm{pH}$ is the dominant factor influencing the decontamination results of both cesium and cobalt. The manufacturing method also affects the decontamination result. However, the appropriate simulation target of each method is different, thus any discussion about the effect of the contamination method on decontamination should be conducted carefully.

The effects of selected variables were examined in detail by plotting the decontamination rate against the $\mathrm{pH}$ and applied electric field. Theoretically, the electrical field and zeta-potential are fundamental parameters of electro-osmosis and electrophoresis velocity (Eq. 9). Zeta potential is not affected by the straightforward output of the electric field applied across the electrodes, but are a complicated result of the chemistry, which is also affected by the $\mathrm{pH}$ of the solution. ${ }^{82}$ Considering that electro-kinetic phenomena are the interaction between the movement of fluid and ions in an EDL system, the rate of electro-osmosis and electrophoresis is related to both the final decontamination ratio (electro-kinetic phenomena should determine the equilibrium of mass transport) and the initial decontamination rate.

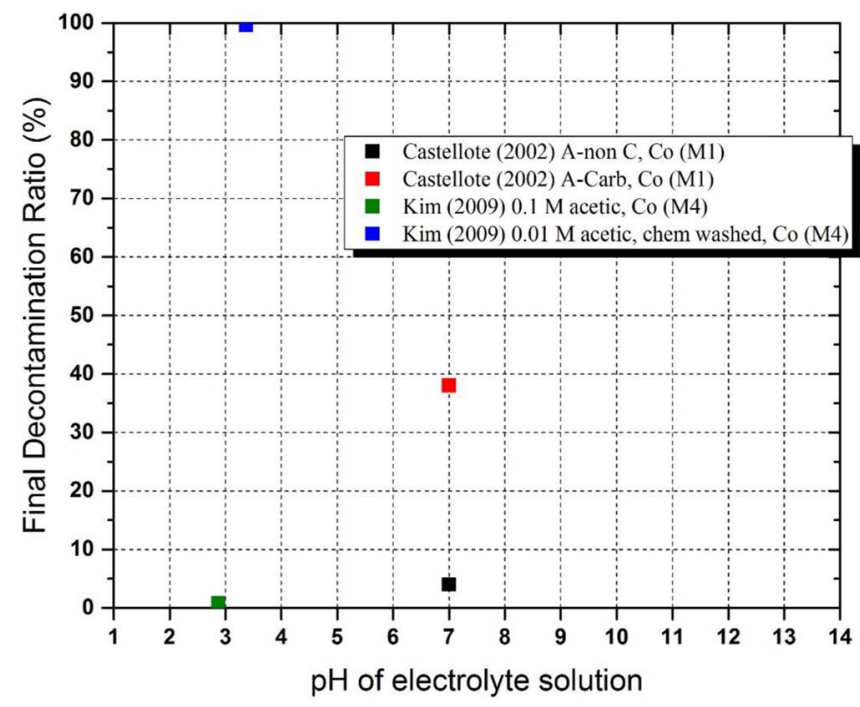

Figure 17. Final decontamination ratio vs. $\mathrm{pH}$ (cobalt). 


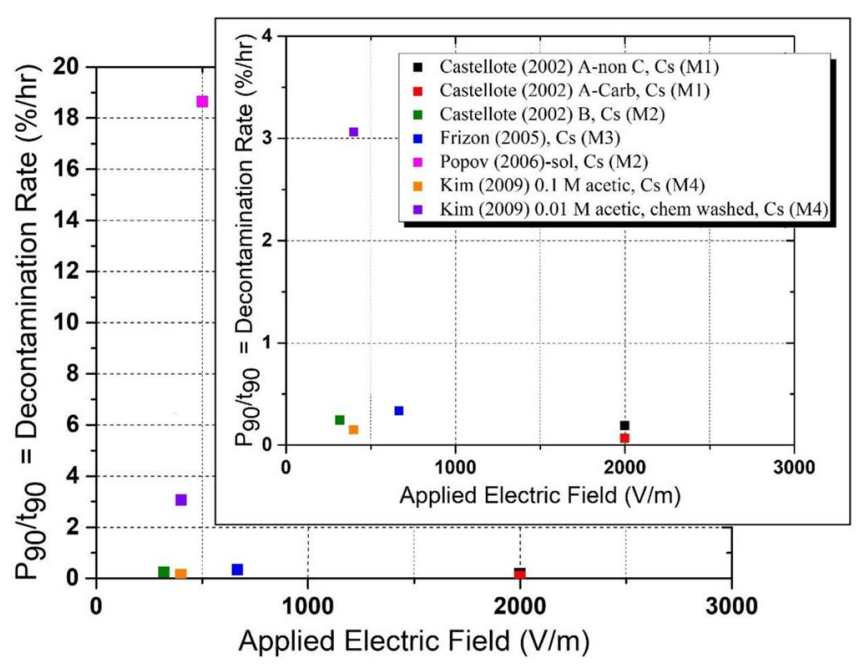

Figure 18. Mean decontamination rate vs. electric field (cesium).

Fig. 16 shows the relationship between the $\mathrm{pH}$ and final decontamination ratio of cesium. Except for the data from the experiment on the carbonated sample of Castellote et al. and the results of Kim et al. who used a chemical washing process, the experiment using a solution with a $\mathrm{pH}$ value close to 7 shows a higher final decontamination ratio. ${ }^{36,39}$

Fig. 17 shows the relationship between $\mathrm{pH}$ and the final decontamination ratio of cobalt. Decontamination of specimens containing cobalt was more strongly affected by the manufacturing condition and decontamination process, rather than by the $\mathrm{pH}$ of the solution.

Fig. 18 shows the relationship between the applied electric field and mean decontamination rate of cesium. Data pertaining to cobalt are excluded from the voltage analysis, because test data are insufficient to figure out the tendency. The mean decontamination rate is expressed by the following equation.

$$
V_{d e c}=\frac{P_{90}}{t_{90}}
$$

Here, $V_{d e c}$ is the mean decontamination rate $(\% / \mathrm{h}), P_{90}$ is a value corresponding to $90 \%$ of the final decontamination ratio, and $t_{90}$ is the time corresponding to $P_{90}$. An increase in the applied electric field seems to be not highly related with the mean decontamination speed. This suggests that the manufacturing process is the dominant factor influencing the mean decontaminate rate regardless of the applied electric field.

Fig. 19 shows the correlation between the applied electric field and the final decontamination ratio of cobalt. It could be verified that when the applied electric field ranges from $500 \mathrm{~V} / \mathrm{m}$ to $2000 \mathrm{~V} / \mathrm{m}$, the final decontamination ratio is increased, except for the carbonated sample of Castellote et al. ${ }^{36}$ In addition, in this case, the carbonation state and manufacturing method also affected the tendency. Considering that Popov et al. and Castellote et al. (series B) used the same category of method, the tendency observed in the electric field range of $500 \mathrm{~V} / \mathrm{m}$ to $2000 \mathrm{~V} / \mathrm{m}$ is more clear and persuasive than the other tendencies in Figs. 16 to $18 .^{36,40}$

Comparison with literature research.-The observed tendency was investigated by conducting additional literature research, which is an extension of the research found in the literature. Earlier in this paper it is noted that the $\mathrm{pH}$ could cause the bonding form of cobalt in concrete to change. In addition, decreasing the $\mathrm{pH}$ of the inner-structure of concrete by using a low-pH solution may induce the dissolution of $\mathrm{Ca}(\mathrm{OH})_{2}$ and $\mathrm{C}-\mathrm{S}-\mathrm{Hs}$. Therefore, the mobility of cobalt in concrete may increase by decreasing the $\mathrm{pH}$ of its environment. ${ }^{83} \mathrm{Kim}$ et al. also noted that the immersion of concrete in acidic solutions causes the dissolution of the calcium carbonate in the concrete (the $\mathrm{pH}$ of the

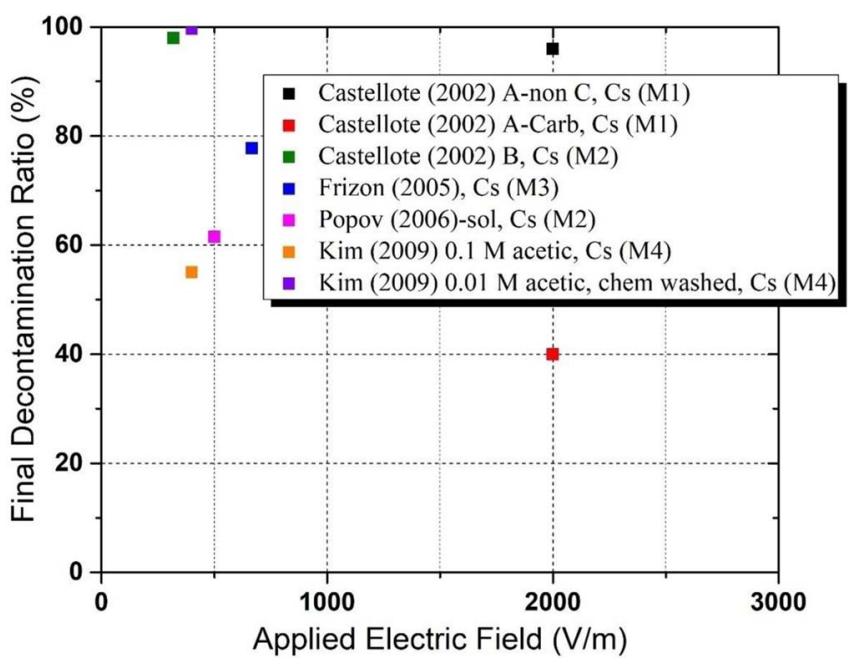

Figure 19. Final decontamination ratio vs. electric field (cesium).

concrete also decreases), and consequently increases the porosity of the concrete. ${ }^{44}$

In Table III, it is clearly shown that the bonding form of cobalt affected the decontamination efficiency. When cobalt existed as cobalt ions in concrete specimens, the decontamination efficiency was relatively high. ${ }^{44}$ When cobalt existed as incorporated elements, the efficiency was relatively low. ${ }^{41}$ Data for the bonding form of cesium are insufficient for conducting reliable analysis. The results of various leaching tests conducted by Achternbosh et al., Hohberg et al., and Nikolayev et al. are examined in Table IV and Table $\mathrm{V}$ as well as in Fig. 20 and Fig. 21 with the aim of developing a deeper understanding of the effects of the use of acidic solutions on the mobility of contaminants in hydrated cement system. ${ }^{6,64,78}$

Van Gerven et al. ${ }^{76}$ researched the solubility of heavy metals in Portland cement mortars by using leachates with various $\mathrm{pH}$ values. Fig. 20 shows the solubility of cobalt as a function of the $\mathrm{pH}$ of the leaching solution. The degree of carbonation was verified by using phenolphthalein solution. The solubility of cobalt increased by more than 15 times when the $\mathrm{pH}$ of the solution was decreased from 9 to 4 . In addition, the leaching rate of cobalt was decreased by the carbonation of the cement system.

Van Gerven et al. also conducted a mass transfer test using the NEN $7345^{25}$ test. $^{84}$ The converted cumulative leaching rate of cobalt for 30

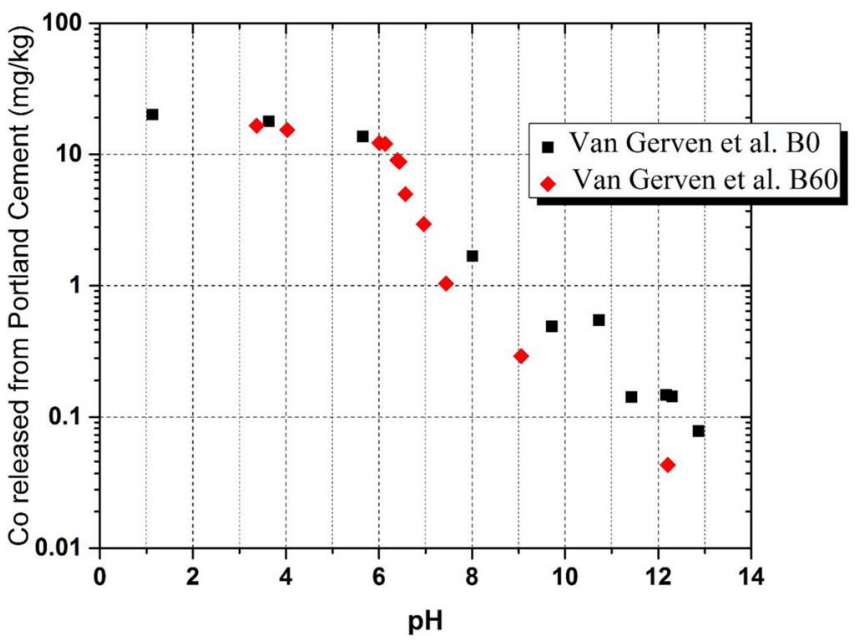

Figure 20. Solubility of cobalt from Portland cement mortars in solutions with various $\mathrm{pH}$ values. ${ }^{76} * \mathrm{~B} 0$ represents uncarbonated samples, whereas B60 denotes nearly completely carbonated samples. 
Table IV. Availability test results for cobalt in concrete ${ }^{78}$ (units: $\left.\mathrm{mg} / \mathrm{kg}\right)$.

\begin{tabular}{|c|c|c|c|c|c|c|c|c|}
\hline \multirow[b]{2}{*}{ Method Parameter } & \multicolumn{2}{|c|}{ Total content } & \multicolumn{2}{|c|}{ Availability $^{\mathrm{a}}$} & \multicolumn{2}{|c|}{ Availability $^{\mathrm{b}}$} & \multicolumn{2}{|c|}{ Availability $^{\mathrm{c}}$} \\
\hline & Mean & $N$ & Mean & $N$ & Mean & $N$ & Mean & $N$ \\
\hline Cobalt & 4 & 7 & 1.2 & 8 & 1.7 & 8 & $<0.03$ & 7 \\
\hline
\end{tabular}

a Procedure according to NEN-ISO 7341; $1^{\text {st }}$ step $3 \mathrm{~h}$ constant $\mathrm{pH}=7,2^{\text {nd }}$ step $3 \mathrm{~h}$ constant $\mathrm{pH}=4$

${ }^{\mathrm{b}}$ Procedure according to NEN-ISO $7341 ; 1^{\text {st }}$ step $3 \mathrm{~h}$ without $\mathrm{pH}$-control, $2^{\text {nd }}$ step $3 \mathrm{~h}$ constant $\mathrm{pH}=4$

${ }^{\mathrm{c}}$ Procedure according to DIN 38414 Teil 4 (DEV-S4 procedure). $1 \mathrm{~h}$ constant $\mathrm{pH}=4$

days in B0 samples was approximately $4.2 \mathrm{mg} / \mathrm{L}$ and $1.94 \mathrm{mg} / \mathrm{kg}$. Table IV summarizes various leaching test results for cobalt in concrete conducted by Hohberg et al. ${ }^{78}$ In this case, decreasing the $\mathrm{pH}$ from 7 to 4 caused the amount of cobalt leaching from concrete to increase by approximately 40 times. The maximum leaching rate was approximately $43 \%$ of the total amount of cobalt ions existing in concrete for 6 hours. Hohberg et al. ${ }^{78}$ clearly verified the effect of the $\mathrm{pH}$ of the leaching solution on the mobility of cobalt in concrete.

In the case of cesium, however, several researchers studied its leaching trend, and concluded that the leaching ratio of cesium is not highly affected by the $\mathrm{pH}$ of the leaching solution. ${ }^{76,77,85}$ Achternbosch et al. suggested that cesium is incorporated in cement paste in the form of Faujasite or Zeolite-P. ${ }^{6}$ The studies of Rahman et al. suggested that cesium is present as free ions in the interstitial pore fluid of the pastes regardless of the hydration state of the other elements in the pore solution. ${ }^{85}$ However, the trend observed by Faiz et al. and Nikolayev et al. differed from that of Rahman et al. for the mobility of cesium. ${ }^{31,77,85}$

Fig. 21 shows the cumulative leaching rate of cesium in Portland cement mortar for different time intervals (0-7 days, 7-16 days, 1623 days, 23-34 days). The leaching rate was minimized at $\mathrm{pH} 7$, and increased as the $\mathrm{pH}$ value increased or decreased from 7 . There was little difference between the maximum and minimum values of the leaching rate of cesium, but this can affect the decontamination of cesium; therefore, we decided to use the data of Faiz et al. ${ }^{77}$ to estimate the leaching ratio of cesium in Table II.

Tables $\mathrm{V}$ presents the phase distribution of ${ }^{137} \mathrm{Cs}$ when an acidic solution was poured onto a concrete specimen. The specimen contains $30-54 \%$ of ${ }^{137} \mathrm{Cs}$ in the fixed form, but the remaining cesium exists in the ion-exchangeable or water-soluble form. Thus, $50-60 \%$ of ${ }^{137} \mathrm{Cs}$ could be extracted easily and did not seem that highly affected by the $\mathrm{pH}$ of the solution. Approximately $5 \%$ of the total amount of ${ }^{137} \mathrm{Cs}$ was strongly bonded to the concrete.

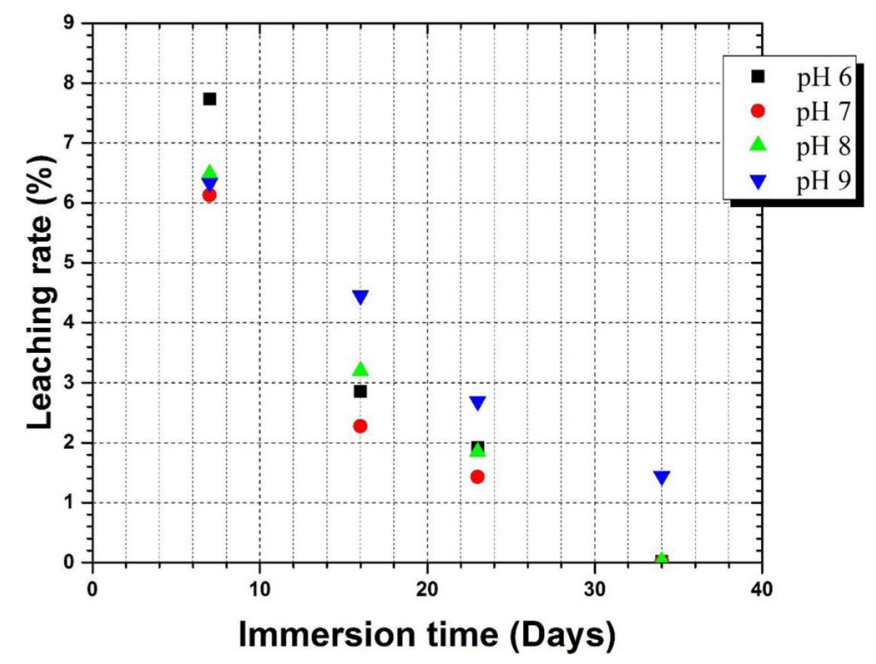

Figure 21. Variation of leaching percentage of ${ }^{134} \mathrm{Cs}$ as a function of the immersion time intervals-Adopted from Faiz et al. ${ }^{77}$

\begin{tabular}{cccc}
\hline $\begin{array}{l}\text { Table } V . \\
\text { to an acidic solution -Adopted from Nikolayev et al. }{ }^{\mathbf{6 4}}\end{array}$ & Cs phase distribution when the concrete wased \\
Parameter & Solution & Suspension & Precipitate \\
\hline Material mass, \% & 46 & 9.6 & 44.4 \\
${ }^{137}$ Cs phase content, $\%$ & 35 & 58 & 7
\end{tabular}

Consequently, it is verified that the $\mathrm{pH}$ of concrete is likely to be an important factor that influences the bonding forms and bonding energy of the contaminants in concrete. The $\mathrm{pH}$ value of concrete at 180 days is typically higher than approximately $9.0 .^{86}$ Therefore, a process designed to decrease the $\mathrm{pH}$ of concrete below that value will help to increase the mobility of contaminants in the concrete and improve the decontamination efficiency.

The amount of cobalt released from concrete differed highly depending on the $\mathrm{pH}$ of the solution. After concrete is immersed in a solution with a $\mathrm{pH}$ value of 4 for several hours, approximately $20 \%-$ $40 \%$ of cobalt can be extracted. The effects of $\mathrm{pH}$ on the release of cesium are expected to be smaller than for cobalt. The release of contaminants was reported even when the mortar samples were immersed in nitric acid, and then immersed in distilled water. From this point of view, both a chemical washing process and the $\mathrm{pH}$ of the electrolyte solution could be key factors for successful decontamination.

\section{Conclusions}

In this paper, we investigates the effects of different cell configurations and operating conditions of electro-kinetic tests on the decontamination ratio and rate of nuclides (such as Cs and Co) from radioactive concrete. In addition, we critically review the conditions and contamination methods of simulated concrete samples in previous experimental studies in comparison with actual nuclear plant data. Potential improvements for the electro-kinetic decontamination methods are suggested based on the following discussions.

It is verified that cobalt, cesium, and europium are the main heavymetal radioactive nuclides in contaminated concrete waste produced from NPPs. Considering previous studies for the leaching and electrokinetic decontamination, the proportion of fixed cesium in concrete seems lower than that of fixed cobalt. Most of radioactive cobalt in contaminated concrete originated from nonradioactive cobalt in cement that had been strongly bonded with cement particles during hydration. Decreasing the $\mathrm{pH}$ of concrete by using a low-pH solution is beneficial to eliminate these incorporated (strongly bonded) elements, by changing them to ions that are easily removable.

To make contaminated concrete specimens similar to those from NPPs, following conditions should be replicated: strong bond between contaminants and cement matrix, variation of concentration over the depth and high concentration of contaminants at the near-surface region, and realistically low concentration of contaminants. Method 1 is appropriate to simulate radiated concrete members, but is incapable of producing a varying distribution of contaminants over the depth. Method 2 is appropriate to simulate floor structures contaminated by an accidental release of nuclides. Methods 3 and 4 can be used to simulate small-size debris samples of radiated concrete. 
The addition of a chemical washing procedure resulted in the highest decontamination efficiency for cobalt with respect to time. However, the effect of chemical washing needs more investigation. The decontamination efficiency for cesium seems to increase in the electrical field range of 500 to $2000 \mathrm{~V} / \mathrm{m}$. For more comprehensive understanding on electro-kinetic decontamination mechanisms, we will continue future research on numerical simulations that take into account the dissolution and immobilization of nuclides.

\section{Acknowledgment}

This work was supported by the Korea Institute of Energy Technology Evaluation and Planning (KETEP) and the Ministry of Trade, Industry \& Energy (MOTIE) of the Republic of Korea (No. 20171510101960).

\section{ORCID}

Sungyeol Choi (D) https://orcid.org/0000-0002-7164-8491

Myoungsu Shin (1D https://orcid.org/0000-0001-6749-8294

\section{References}

1. K. Dickerson, M. Wilson-Nichols, and M. Morris, Contaminated concrete: Occurrence and emerging technologies for DOE decontamination, in, Oak Ridge National Lab., TN (United States), 1995.

2. H. Hilsdorf, J. Kropp, and H. Koch, "The effects of nuclear radiation on the mechanical properties of concrete," ACI SP-55, 223 (1978).

3. I.A.E. AGENCY, Managing Low Radioactivity Material from the Decommissioning of Nuclear Facilities, INTERNATIONAL ATOMIC ENERGY AGENCY, Vienna, 2008

4. B.-Y. Min, J.-W. Park, W.-K. Choi, and K.-W. Lee, "Separation of Radionuclide from Dismantled Concrete Waste," Journal of Nuclear Fuel Cycle and Waste Technology (JNFCWT), 7, 79 (2009)

5. S.-J. Yun, "The Ideological Basis and the Reality of Low Carbon Green Growth," Eco, 13, 219266 (2009).

6. M. Achternbosch, K. Bräutigam, N. Hartlieb, C. Kupsch, U. Richers, P. Stemmermann, and M. Gleis, Heavy metals in cement and concrete resulting from the co-incineration of wastes in cement kilns with regard to the legitimacy of waste utilisation, Forschungszentrum Karlsruhe GmbH, Karlsruhe, (2003).

7. E. Arifi, K. Ishimatsu, S. Iizasa, T. Namihira, H. Sakamoto, Y. Tachi, H. Kato, and M. Shigeishi, "Reduction of contaminated concrete waste by recycling aggregate with the aid of pulsed power discharge," Construction and Building Materials, 67, 192 (2014)

8. U. Chung, K. Lee, D. Hwang, S. Park, S. Hwang, S. Paik, J. Park, Y. Choi, K. Chung, and K. Lee, Current status of decommissioning projects and their strategies in advanced countries, in, Korea Atomic Energy Research Institute, 2007.

9. W.N. Association, Decommissioning Nuclear Facilities, in, 2016.

10. U.S.NRC, Backgrounder on Decommissioning Nuclear Power Plants, in, U.S.NRC, 2015

11. K. Menyah and Y. Wolde-Rufael, " $\mathrm{CO}_{2}$ emissions, nuclear energy, renewable energy and economic growth in the US," Energy Policy, 38, 2911 (2010).

12. I.A.E. AGENCY, Status of the Decommissioning of Nuclear Facilities around the World, INTERNATIONAL ATOMIC ENERGY AGENCY, Vienna, 2004.

13. M. D. Kaminski, S. D. Lee, and M. Magnuson, "Wide-area decontamination in an urban environment after radiological dispersion: A review and perspectives," Journal of hazardous materials, 305, 67 (2016)

14. A. Anthofer, W. Lippmann, and A. Hurtado, "Laser decontamination of epoxy painted concrete surfaces in nuclear plants," Optics \& Laser Technology, 57, 119 (2014).

15. Z. P. Bazant and G. Zi, "Decontamination of radionuclides from concrete by microwave heating. I: theory," Journal of engineering mechanics, 129, 777 (2003).

16. D. Echert, M. Hashish, and M. Marvin, Abrasive waterjet cutting of thick concrete and waterjet cleaning for nuclear facility decommissioning and decontamination, in: International Decommissioning (Proc. Int. Symp. Pittsburgh, 1987), 1987.

17. A. B. Fabrice Moggia, Thierry Varet, Valérie Toulemonde, Frédéric Richard, Gary Anderson, and Frédérique Damerval, Nitrojet: A Versatile Tool for Decontamination, Cutting and Concrete Scabbling- 11225in: WM2011, Phoenix, Arizona, 2011.

18. V. Goldfarb and R. Gannon, Concrete decontamination by electro-hydraulic scabbling, in: Proceedings of the Environmental Technology Through Industry Partnership Conference, 1995, pp. 225

19. W. S. Kim, G. N. Kim, D. B. Shon, H. M. Park, K. H. Kim, K. W. Lee, K. W. Lee, and J. K. Moon, Effect of Particle-size Distribution on Chemical Washing Experiment of Uranium Contaminated Concrete, (2011).

20. T. W. Lynch, Diamond blade grinding as a means for removing surface contamination from concrete, in, 1980.

21. P. O'Sullivan, J. Nokhamzon, and E. Cantrel, "Decontamination and dismantling of radioactive concrete structures," NEA News, 28, 27 (2010).
22. T. White, R. Grubb, L. Pugh, D. Foster Jr, and W. Box, "Removal of Contaminated Concrete Surfaces by Microwave Heating-Phase I Results," WASTE MANAGEMENTTUCSON-, 745 (1992).

23. T. L. White, D. Foster Jr, C. T. Wilson, and C. R. Schaich, Phase II microwave concrete decontamination results, ORNL Rep. No. De-AC05-84OR21400, (1995).

24. B. L. Woods and R. Gossett, Application of diamond tools when decontaminating concrete, in, 1980

25. J. L. Nelson and J. Divine, Decontamination Processes for Restorative Operations and as a Precursor to Decommissioning: A Literature Review, in, Pacific Northwest National Laboratory (PNNL), Richland, WA (United States), 1981.

26. R. Castellani, A. Poulesquen, F. Goettmann, P. Marchal, and L. Choplin, "Efficiency enhancement of decontamination gels by a superabsorbent polymer," Colloids and Surfaces A: Physicochemical and Engineering Aspects, 454, 89 (2014).

27. D. Gurau and R. Deju, "The use of chemical gel for decontamination during decommissioning of nuclear facilities," Radiation Physics and Chemistry, 106, 371 (2015).

28. A. Jestin, P. Thouvenot, M. Libert, and J. P. Bournazel, A concrete biodecontamination process in nuclear substructures: effects of organic acids

29. M. D. Kaminski, M. R. Finck, and C. J. Mertz, Composition suitable for decontaminating a porous surface contaminated with cesium, in, Google Patents, 2010.

30. M. Koh, J. Yoo, M. Ju, B. Joo, K. Park, H. Kim, H. Kim, and B. Fournel, "Surface decontamination of radioactive metal wastes using acid-in-supercritical $\mathrm{CO}_{2}$ emulsions," Industrial \& Engineering Chemistry Research, 47, 278 (2008).

31. A. Nikolaev, O. Karlina, A. Y. Yurchenko, and Y. V. Karlin, "Assessment of 137C decontamination of concrete by the reagent method," Atomic Energy, 112, 57 (2012).

32. M. Harris, D. DePaoli, and M. Ally, "Modeling the electrokinetic transport of strontium and cesium through a concrete disk," Separation and purification technology, 11, 173 (1997).

33. K. Archibald, R. Demmer, M. Argyle, L. Lauerhass, and J. Tripp, Cleaning and Decontamination using Strippable and Protective Coatings at the Idaho National Engineering and Environmental Laboratory, in, INEEL/CON-98-00797, WM'99 Conference, 1999

34. W. D. B. Bostick, S. A. Marsh, G. C. Henson, H. M. Box, and W. D. Morgan, I. L. Electroosmotic decontamination of concrete, (1993).

35. M. Castellote, C. Andrade, and C. Alonso, Application of electrical fields in the study of concretes with respect to the transport of several ionic species present in radioactive wastes: characterisation and decontamination, in: Proceedings of the 16th International Conference on Structural Mechanics in Reactor Technology (SmiRT 16), Paper, 2001

36. M. Castellote, C. Andrade, and C. Alonso, "Nondestructive decontamination of mortar and concrete by electro-kinetic methods: application to the extraction of radioactive heavy metals," Environmental science \& technology, 36, 2256 (2002).

37. F. Frizon, S. Lorente, and C. Auzuech, "Nuclear decontamination of cementitious materials by electrokinetics: An experimental study," Cement and Concrete Research, 35, 2018 (2005)

38. G.-N. Kim, Y.-H. Jung, J.-J. Lee, J.-K. Moon, and C.-H. Jung, "An analysis of a flushing effect on the electrokinetic-flushing removal of cobalt and cesium from a soil around decommissioning site," Separation and purification technology, 63, 116 (2008).

39. G.-N. Kim, B.-I. Yang, W.-K. Choi, K.-W. Lee, and J.-H. Hyeon, "Washingelectrokinetic decontamination for concrete contaminated with Cobalt and Cesium," Nuclear Engineering and Technology, 41, 1079 (2009).

40. K. Popov, I. Glaskova, S. Myagkov, and A. Petrov, "Removal of cesium from the porous surface via the electrokinetic method in the presence of a chelating agent," Colloid Journal, 68, 743 (2006)

41. K. Popov, I. Glazkova, V. Yachmenev, and A. Nikolayev, "Electrokinetic remediation of concrete: effect of chelating agents," Environmental pollution, 153, 22 (2008)

42. M. Tan, J. D. Whitaker, and D. T. Schwartz, "Simulation study on the use of strippable coatings for radiocesium decontamination of concrete," Journal of hazardous materials, 162, 1111 (2009).

43. D. DePaoli, M. Harris, and M. Ally, Testing and evaluation of electrokinetic decontamination of concrete, in, Oak Ridge National Lab., TN (United States), 1996.

44. G. N. Kim, B. Y. Yang, W. K. Choi, B. Y. Min, K. W. Lee, and U. S. Chung, "Study on Radioactive Concrete Decontamination performed by Electrochemical Extraction," Journal of Korean Radioactive Waste Society, 7, 61 (2009).

45. M. T. Harris, D. W. DePaoli, and M. R. Ally, "Modeling the electrokinetic decontamination of concrete," Separation science and technology, 32, 827 (1997).

46. G.-N. Kim, W.-K. Choi, and K.-W. Lee, "Decontamination of radioactive concrete using electrokinetic technology," Journal of applied electrochemistry, 40, 1209 (2010).

47. J.-C. Alder, "Preliminary studies of packaging and disposal of decommissioning waste in Switzerland," Nuclear Technology, 86, 197 (1989).

48. S.G. IAEA, Terminology used in nuclear safety and radiation protection, 2007 edition, IAEA, Vienna, (2007)

49. I.A.E. AGENCY, Disposal Aspects of Low and Intermediate Level Decommissioning Waste, INTERNATIONAL ATOMIC ENERGY AGENCY, Vienna, 2007.

50. K. Schneider, C. Jenkins, and R. Rhoads, Technology, safety, and costs of decommissioning a reference nuclear fuel reprocessing plant, in, Battelle Pacific Northwest Labs., Richland, Wash.(USA), 1977.

51. I.A.E. AGENCY, Radiological Characterization of Shut Down Nuclear Reactors for Decommissioning Purposes, INTERNATIONAL ATOMIC ENERGY AGENCY, Vienna, 1998.

52. A. Harms and C. Gilligan, "Development of a neutron-activated concrete powder reference material," Applied radiation and isotopes: including data, instrumentation and methods for use in agriculture, industry and medicine, 68, 1471 (2010); discussion $1475-1476$ 
53. J. Evans, E. Lepel, R. Sanders, C. Wilkerson, W. Silker, C. Thomas, K. Abel, and D. Robertson, Long-lived activation products in reactor materials, in, Pacific Northwest Lab., Richland, WA (USA), 1984.

54. R. I. Smith, G. Konzek, and W. Kennedy Jr, Technology, safety, and costs of decommissioning a reference pressurized water reactor power station. Appendices, in, Battelle Pacific Northwest Labs., Richland, WA (USA), 1978.

55. J. Krasznai, "The radiochemical characterization of regular-and high-density concrete from a decommissioned reactor," Waste Management, 13, 131 (1993).

56. K. Adinarayana, P. Sasidhar, and V. Balasubramaniyan, "Modelling of calcium leaching and its influence on radionuclide migration across the concrete engineered barrier in a NSDF," Journal of environmental radioactivity, 124, 93 (2013).

57. G. Eichholz, W. Park, and C. Hazin, "Tritium penetration through concrete," Waste Management, 9, 27 (1989).

58. K. Furuichi, H. Takata, K. Katayama, T. Takeishi, M. Nishikawa, T. Hayashi, K. Kobayashi, and H. Namba, "Evaluation of tritium behavior in concrete," Journal of Nuclear Materials, 367, 1243 (2007).

59. D. J. Kim, P. E. Warwick, and I. W. Croudace, "Tritium speciation in nuclear reactor bioshield concrete and its impact on accurate analysis," Analytical chemistry, 80, 5476 (2008).

60. X. Hou, "Rapid analysis of $14 \mathrm{C}$ and $3 \mathrm{H}$ in graphite and concrete for decommissioning of nuclear reactor," Applied Radiation and Isotopes, 62, 871 (2005).

61. L. M. Haselbach and S. Ma, "Potential for carbon adsorption on concrete: Surface XPS analyses," Environmental science \& technology, 42, 5329 (2008).

62. A. D. Ebner, J. A. Ritter, and J. D. Navratil, "Adsorption of cesium, strontium, and cobalt ions on magnetite and a magnetite- silica composite," Industrial \& Engineering Chemistry Research, 40, 1615 (2001).

63. T. Valsala, S. Roy, J. Shah, J. Gabriel, K. Raj, and V. Venugopal, "Removal of radioactive caesium from low level radioactive waste (LLW) streams using cobalt ferrocyanide impregnated organic anion exchanger," Journal of hazardous materials, 166, 1148 (2009).

64. A. Nikolaev, O. Karlina, A. Y. Yurchenko, and Y. V. Karlin, "Assessment of 137 Cs decontamination of concrete by the reagent method," Atomic Energy, 1 (2012)

65. J. Hoefs and J. Hoefs, Stable isotope geochemistry, Springer, 1980.

66. G. Bar-Nes, A. Katz, Y. Peled, and Y. Zeiri, "The mechanism of cesium immobilization in densified silica-fume blended cement pastes," Cement and Concrete Research, 38, 667 (2008).

67. A. Delgado, F. González-Caballero, R. Hunter, L. Koopal, and J. Lyklema, "Measurement and interpretation of electrokinetic phenomena (IUPAC technical report)," Pure and Applied Chemistry, 77, 1753 (2005).

68. Á. V. Delgado, F. González-Caballero, R. Hunter, L. Koopal, and J. Lyklema, "Measurement and interpretation of electrokinetic phenomena," Journal of colloid and interface science, 309, 194 (2007).
69. D. Erickson, "Electroosmotic Flow (DC)," Encyclopedia of Microfluidics and Nanofluidics, 1 (2013).

70. S.-s. Kim and S.-j. Han, Electrokinetic Contaminated Soil Remediation Technologies for construction, ground environment engineers, (2003).

71. A. J. Parker, C. Boxall, and M. J. Joyce, An Evaluation of Electrokinetic Transport of Radioactive Species through Concrete for Application as a Non-Destructive In Situ Remediation Technique-14102, (2014).

72. C. AsTM, 1202, Rapid Chloride Permeability, (1997).

73. M. Castellote and S. Botija, "Electrokinetic decontamination of heavy metals in construction materials: contribution of the different parameters to the global efficiency," Journal of applied electrochemistry, 41, 695 (2011).

74. G.-N. Kim, S.-S. Kim, U.-R. Park, and J.-K. Moon, "Decontamination of Soil Contaminated with Cesium using Electrokinetic-electrodialytic Method," Electrochimica Acta, 181, 233 (2015).

75. H. Lomasney, Electrokinetic decontamination of concrete, in, Isotron Corp., New Orleans, LA (United States), 1995.

76. T. Van Gerven, G. Cornelis, E. Vandoren, C. Vandecasteele, A. Garrabrants, F. Sanchez, and D. Kosson, "Effects of progressive carbonation on heavy metal leaching from cement-bound waste," AIChE journal, 52, 826 (2006).

77. Z. Faiz, S. Fakhi, A. Bouih, R. Outayad, A. Benkdad, and H. Hannache, "Leaching study of cesium from spent ion-exchange resins and Portland cement package," International Journal of Environmental Science and Technology, 1.

78. I. Hohberg, G. De Groot, A. Van der Veen, and W. Wassing, "Development of a leaching protocol for concrete," Waste Management, 20, 177 (2000).

79. I. Plecas, "Effect of curing time on the fraction of Cs 137 from cement matrix," Annals of Nuclear Energy, 30, 1587 (2003).

80. I. Mostinsky, Diffusion coefficient, in, CRC Press, Florida, USA. DOI, 1996.

81. J. De Goeij and M. Bonardi, "How do we define the concepts specific activity, radioactive concentration, carrier, carrier-free and no-carrier-added?," Journal of radioanalytical and nuclear chemistry, 263, 13 (2005).

82. B. J. Kirby and E. F. Hasselbrink, "Zeta potential of microfluidic substrates: 1. Theory, experimental techniques, and effects on separations," Electrophoresis, 25, 187 (2004).

83. J. M. Soler, Thermodynamic description of the solubility of CSH gels in hydrated Portland cement, Posiva Oy, 2007.

84. E. NEN, 7375: 2004, Leaching characteristics of moulded or monolithic building and waste materials, (2004).

85. R. A. Rahman, D. Z. El Abidin, and H. Abou-Shady, "Cesium binding and leaching from single and binary contaminant cement-bentonite matrices," Chemical Engineering Journal, 245, 276 (2014).

86. V. Räsänen and V. Penttala, "The $\mathrm{pH}$ measurement of concrete and smoothing mortar using a concrete powder suspension," Cement and Concrete Research, 34, 813 (2004). 